Review

\title{
Anti-Cancer Effects of Green Tea Epigallocatchin-3-Gallate and Coffee Chlorogenic Acid
}

\author{
Sumio Hayakawa ${ }^{1, *}$, Tomokazu Ohishi ${ }^{2}{ }^{(D}$, Noriyuki Miyoshi ${ }^{3}\left(\mathbb{D}\right.$, Yumiko Oishi $^{1}{ }^{1}$, \\ Yoriyuki Nakamura ${ }^{3}$ and Mamoru Isemura ${ }^{3, *(\mathbb{D}}$ \\ 1 Department of Biochemistry and Molecular Biology, Graduate School of Medicine, Nippon Medical School, \\ Bunkyo-ku, Tokyo 113-8602, Japan; y-oishi@nms.ac.jp \\ 2 Institute of Microbial Chemistry (BIKAKEN), Numazu, Microbial Chemistry Research Foundation, \\ Shizuoka 410-0301, Japan; ohishit@bikaken.or.jp \\ 3 School of Nutritional and Environmental Sciences, University of Shizuoka, Suruga-ku, Shizuoka 422-8526, \\ Japan; miyoshin@u-shizuoka-ken.ac.jp (N.M.); yori.naka222@u-shizuoka-ken.ac.jp (Y.N.) \\ * Correspondence: hayakawa_sci@icloud.com (S.H.); isemura@u-shizuoka-ken.ac.jp (M.I.); \\ Tel.: +81-3-3822-2131 (S.H.); +81-54-264-5920 (M.I.)
}

Received: 20 August 2020; Accepted: 28 September 2020; Published: 5 October 2020

\begin{abstract}
Tea and coffee are consumed worldwide and epidemiological and clinical studies have shown their health beneficial effects, including anti-cancer effects. Epigallocatechin gallate (EGCG) and chlorogenic acid (CGA) are the major components of green tea polyphenols and coffee polyphenols, respectively, and believed to be responsible for most of these effects. Although a large number of cell-based and animal experiments have provided convincing evidence to support the anti-cancer effects of green tea, coffee, EGCG, and CGA, human studies are still controversial and some studies have suggested even an increased risk for certain types of cancers such as esophageal and gynecological cancers with green tea consumption and bladder and lung cancers with coffee consumption. The reason for these inconsistent results may have been arisen from various confounding factors. Cell-based and animal studies have proposed several mechanisms whereby EGCG and CGA exert their anti-cancer effects. These components appear to share the common mechanisms, among which one related to reactive oxygen species is perhaps the most attractive. Meanwhile, EGCG and CGA have also different target molecules which might explain the site-specific differences of anti-cancer effects found in human studies. Further studies will be necessary to clarify what is the mechanism to cause such differences between green tea and coffee.
\end{abstract}

Keywords: cancer; tea; coffee; EGCG; chlorogenic acid; ROS; AMPK; NF-кB

\section{Introduction}

Green tea is produced by processing of leaves of the plant Camellia sinensis (Theaceae) and is popularly consumed worldwide. Green tea has been shown to have beneficial effects on human health such as anti-cancer, anti-obesity, anti-diabetic, anti-cardiovascular, anti-infectious and anti-neurodegenerative effects [1,2]. (-)-Epigallocatechin gallate (EGCG) is the most abundant catechin in green tea and believed to be mostly responsible for these biological effects (Figure 1). A cup of green tea typically brewed from $2.5 \mathrm{~g}$ of tea leaves contains $240-320 \mathrm{mg}$ of catechins, of which EGCG accounts for $60-65 \%$ [3]. 
<smiles>O=C(O[C@H]1Cc2c(O)cc(O)cc2O[C@H]1c1cc(O)c(O)c(O)c1)c1cc(O)c(O)c(O)c1</smiles>

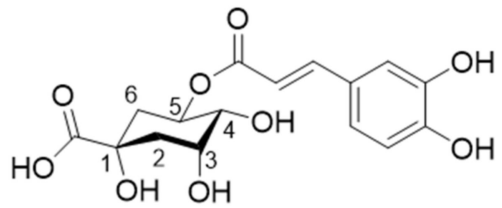

CGA

\section{EGCG}

Figure 1. Chemical structures of EGCG and CGA.

Black tea is produced also from C. sinensis through enzymatic processing (so called fermentation) by intrinsic enzymes and microorganisms during which catechins can be polymerized to give catechin derivatives such as theaflavins and theasinensins [4]. Black tea has been shown to have physiological effects similar to those of green tea with lesser effects as compared with green tea due to its lower content of EGCG.

Coffee is also consumed worldwide and has various health effects. It contains about 2000 different chemicals and the major polyphenols are chlorogenic acid (CGA, Figure 1) and its derivatives which amount to about $3 \% w / w$ of roasted coffee powder [2,5]. A single cup of coffee may contain 20-675 mg of CGAs [6].

In this review, we discuss recent evidence from human studies to support the anti-cancer effects of consumption of green tea and coffee and mechanistic aspects of the actions of EGCG and CGA based on the results of cell-based and animal experiments. After the International Union of Pure and Applied Chemistry reversed the order of numbering of atoms on the quinic acid ring in 1976 and suggested the name 5-caffeoylquinic acid for chlorogenic acid instead of 3-caffeoylquinic acid [7,8], there has been some confusion in the nomenclature of chlorogenic acid. In this review, we use the term CGA according to the respective authors' description. Caffeine is contained abundantly in tea and coffee and may contribute to the anti-cancer effects of these beverages. However, cell-based and animal studies have shown that EGCG as well as CGA exert anti-cancer effects by themselves as shown below. Therefore, for the safe of clarity, the current review focuses on EGCG and CGA but excludes any discussion on caffeine, which has already been comprehensively reviewed [9-12].

\section{Anti-Cancer Effects of Green Tea}

\subsection{Human Studies on Green Tea}

Several epidemiological studies have shown the anti-cancer effects of consumption of tea. A survey in 2013 conducted by Yang and Hong of prospective cohort and case controlled studies which had been reported by 2008 revealed that green tea consumption showed risk-reduction in a total of 39 cases of breast, colon, esophagus, kidney/bladder, lung, ovary, pancreas, prostate, stomach cancers, whereas 46 cases showed no risk-reduction $[1,13]$. In the case of black tea, 28 and 92 cases showed risk-reduction and no risk-reduction, respectively, for these cancers [13]. These findings suggest that green and black teas have a preventive effect in some types of cancer.

When observational epidemiological studies were reviewed on over 1,100,000 participants from 46 cohort studies and 85 case-control studies [14], in three studies involving 52,479 participants, a lower overall cancer incidence (summary relative risk $(R R)=0.83,95 \%$ confidence interval $(C I)=0.65-1.07$ ) was found for the highest intake of green tea compared with the lowest consumption. For most of the site-specific cancers, a decreased RR was found by this comparison. However, results were conflicting, 
since cohort studies in some cancer sites such as oesophageal, prostate and urinary tract cancer showed an increased RR. Table 1 added to show the effects of green tea on cancer, further explained in later text.

Table 1. Recent observational epidemiological studies on anti-cancer effects of green tea.

\begin{tabular}{|c|c|c|c|c|}
\hline Cancer Type & $\begin{array}{l}\text { Evaluation: Decrease }(\downarrow) \text { or No } \\
\text { Effect }(+/-) \text { in Cancer Risk }\end{array}$ & $\begin{array}{l}\text { Hazard Risk (HR) or Odds Ratio } \\
\text { (OR) or Relative Risk (RR) } \\
\text { [Confidence Interval] }\end{array}$ & Note & Reference \\
\hline Breast cancer & $\downarrow$ & $\begin{array}{c}\mathrm{HR}=0.82[0.70-0.95] \text { for } \geq 5 \mathrm{vs} . \\
0 \text { cups } / \text { day }\end{array}$ & $\begin{array}{l}\text { Cohort study onwomen } \\
\text { with family history of } \\
\text { breast cancer }\end{array}$ & [15] \\
\hline Breast cancer & $\downarrow$ & $\begin{array}{c}\mathrm{HR}=0.86[0.75-0.99] \text { for highest vs. } \\
\text { lowest intake }\end{array}$ & $\begin{array}{l}\text { Meta-analysis of } 16 \text { cohort } \\
\text { and case-control studies }\end{array}$ & [16] \\
\hline Breast cancer & $\downarrow$ & $\mathrm{OR}=0.83[0.72-0.96]$ & $\begin{array}{l}\text { Meta-analysis of } 14 \\
\text { case-control studies }\end{array}$ & [17] \\
\hline Colorectal cancer & $+/-$ & & $\begin{array}{l}\text { Cohort study on men } \\
\text { and women }\end{array}$ & [18] \\
\hline Colon cancer & $\downarrow$ & $\begin{array}{c}\mathrm{RR}=1.32[0.90-1.94] \text { for once/day vs. } \\
\text { less than once/day } \mathrm{RR}=0.76 \\
{[0.57-1.02] \text { for } 2-3 \text { times/day }} \\
\mathrm{RR}=0.78[0.49-1.22] \text { for } \geq 4 \text { times/day }\end{array}$ & Cohort study on men & [18] \\
\hline $\begin{array}{l}\text { Head and neck } \\
\text { squamous cell } \\
\text { carcinoma }\end{array}$ & $\downarrow$ & $\begin{array}{c}\mathrm{OR}=0.29[0.16-0.52] \text { for }<1 \mathrm{cup} / \text { day } \\
\text { vs. no intake OR }=0.38[0.17-0.86] \text { for } \\
\geq 1 \text { cup/day vs. no intake }\end{array}$ & $\begin{array}{l}\text { Case-control studyon men } \\
\text { and women }\end{array}$ & [19] \\
\hline $\begin{array}{l}\text { Hematologic } \\
\text { neoplasms }\end{array}$ & $\downarrow$ & $\begin{array}{c}\mathrm{HR}=0.65[0.42-1.00] \text { for } \leq 2 \text { cups/day } \\
\text { vs. no intake HR }=0.73[0.47-1.13] \text { for } \\
3-4 \text { cups/day vs. no intake } \mathrm{HR}=0.63 \\
{[0.42-0.96] \text { for } \geq 5 \text { cups/day vs. }} \\
\text { no intake }\end{array}$ & $\begin{array}{l}\text { Cohort studyon men } \\
\text { and women }\end{array}$ & [20] \\
\hline Total cancer & $\downarrow$ & $\begin{array}{l}\mathrm{HR}=0.89[0.83-0.96] \text { for } 1-2 \text { cups/day } \\
\text { vs. }<1 \text { cup/day } \mathrm{HR}=0.91[0.85-0.98] \\
\text { for } 3-4 \text { cups/day vs. }<1 \text { cup/day }\end{array}$ & $\begin{array}{l}\text { Meta-analysis on } 8 \text { cohort } \\
\text { study on women }\end{array}$ & [21] \\
\hline
\end{tabular}

A recent review of 144 randomized controlled trials (RCTs) and case-control studies also provided evidence for beneficial effect of green tea in some cancer sites [14]. For example, the summary RR of prostate cancer in the green tea-supplemented participants was $0.50(\mathrm{CI}=0.18-1.36)$ on the basis of three RCTs on 201 participants. However, the summary RR from 2 studies for gynecological cancer was 1.50 ( $\mathrm{CI}=0.41-5.48)$, indicating conflicting outcomes for some cancer sites.

In a recent survey of epidemiological studies reported from 2014 to 2018 on tea's anti-cancer effects, $\mathrm{Xu}$ et al. [22] found that 5 and 2 studies of total 11 studies showed favorable and unfavorable effects of tea consumption, respectively, while 4 studies gave no effect, indicating a difficulty in drawing any conclusion.

More recent PubMed data search for human studies published from 2019 to April 2020 provided several papers showing anti-cancer effects of green tea [15-21] (Table 1). For example, in a population-based prospective cohort study in which 13,957 men and 16,374 women participated, the multiple-adjusted colon cancer RR $(0.78, C I=0.49-1.22)$ of men consuming $\geq 4$ times of green tea daily was lower than that of the $<1$ time consumers, although no significant associations between green tea consumption and colorectal cancer (CRC) risk were found in men and women [18]. However, the same search revealed that 3 studies for cervical, liver and stomach cancers did not show significant risk reduction by green tea consumption [23-25]. Thus, human studies found health benefits of green tea consumption in many cases, but it is also true that there are several conflicting results probably due to incomplete elimination of confounding factors.

Polyphenon $^{\circledR} \mathrm{E}$ is a standardized catechin preparation of green tea extract which was approved by the United States Food and Drug Administration in 2006 under the name of sinecatechins for the topical treatment of genital warts [26]. Its efficacy has been proven by several clinical studies as exemplified by a systematic review of three clinical trials in which Polyphenon ${ }^{\circledR} \mathrm{E}$ treatments resulted in significantly higher rates of complete clearance of baseline and new warts compared with controls with very low recurrence rates [27]. Genital warts are caused by human papilloma viruses (HPVs) such as types 6, 11 and 16 [28]. 
In view of successful application to various types of viral agents, Polyphenon ${ }^{\circledR}$ E may be expected to be useful for the possible application to HPV-associated cancers such as cervical cancer and lymphocytic leukemia. A clinical trial in which 51 patients with HPV-infected cervical lesions were treated with Polyphenon ${ }^{\circledR}$ E ointment or capsules or both, resulted in an overall $69 \%$ response rate as compared with that of $10 \%$ in untreated groups [29].

In a phase II trial on 42 patients with asymptomatic, chronic lymphocytic leukemia, it caused a sustained reduction of $\geq 20 \%$ of the absolute lymphocyte count in $31 \%$ of patients and $\geq 50 \%$ reduction in palpable lymphadenopathy in $69 \%$ patients [30]. Thus, future clinical intervention studies with Polyphenon ${ }^{\circledR}$ E could lead to clear evidence for the anti-cancer effects of green tea.

\subsection{Basic Research on Anti-Cancer Action of Green Tea and EGCG}

A large number of cell-based and animal studies have provided evidence to support EGCG's anti-cancer effects. For example, Wang et al. [31] demonstrated that EGCG decreased the numbers of intestinal aberrant crypt foci and colorectal tumors in rats treated with dimethylhydrazine. In a review article, Aggarwal et al. [32] summarized the results of 30 cell-based and 26 murine studies. Also, a comprehensive review by Gan et al. [33] summarized 63 cell-based studies reported in 2001-2015 and 21 animal studies reported in 2007-2015 which demonstrated the anti-cancer effects of EGCG. These authors suggested that these anti-cancer effects may be not due to EGCG itself but to its intracellular metabolites in view of EGCG's low bioavailability.

These basic studies have also proposed mechanisms under which EGCG exerts these effects [1-5]. This review focuses mechanisms related to anti-oxidant and pro-oxidant effects, anti-inflammatory effects, anti-angiogenic effects, induction of apoptosis, modulation of epigenetic pathways and EGCG's binding to cancer-related proteins which have been reviewed in many articles [26,34-39].

\subsection{Mechanisms for Anti-Cancer Effects of EGCG}

\subsubsection{Anti-Oxidant and Pro-Oxidant Effects}

EGCG is a prominent anti-oxidant and quenches reactive oxygen species (ROS), which facilitate oxidative DNA damage, mutagenesis, and tumor promotion, leading to anti-cancer effects [40]. EGCG can exhibit anti-oxidant activity through several mechanisms including catalytic metal chelation, hydrogen atom transfer, and electron transfer. Chemically, the anti-oxidant activity of EGCG can be interpreted by the existence of the polyhydroxyl structure and the gallate group which play key roles to scavenge free radicals and by the presence of phenolic groups with sensitivity to be oxidized, resulting in generation of a quinone [37,41]. Figure 2 illustrates a possible pathway through which EGCG exerts its anti-cancer actions via an anti-oxidant activity on the basis of present and previous findings and discussions [2,22,26,34,37,38,42-44]. Modulation of 5'-AMP activated protein kinase (AMPK) by tumor necrosis factor $\alpha$ (TNF- $\alpha$ ) is incorporated into Figure 2 based on the finding by Steinberg et al. [45] that TNF- $\alpha$ suppresses AMPK activity via transcriptional upregulation of protein phosphatase- $2 \mathrm{C}$, although this link remains to be explored in experiments using EGCG. 


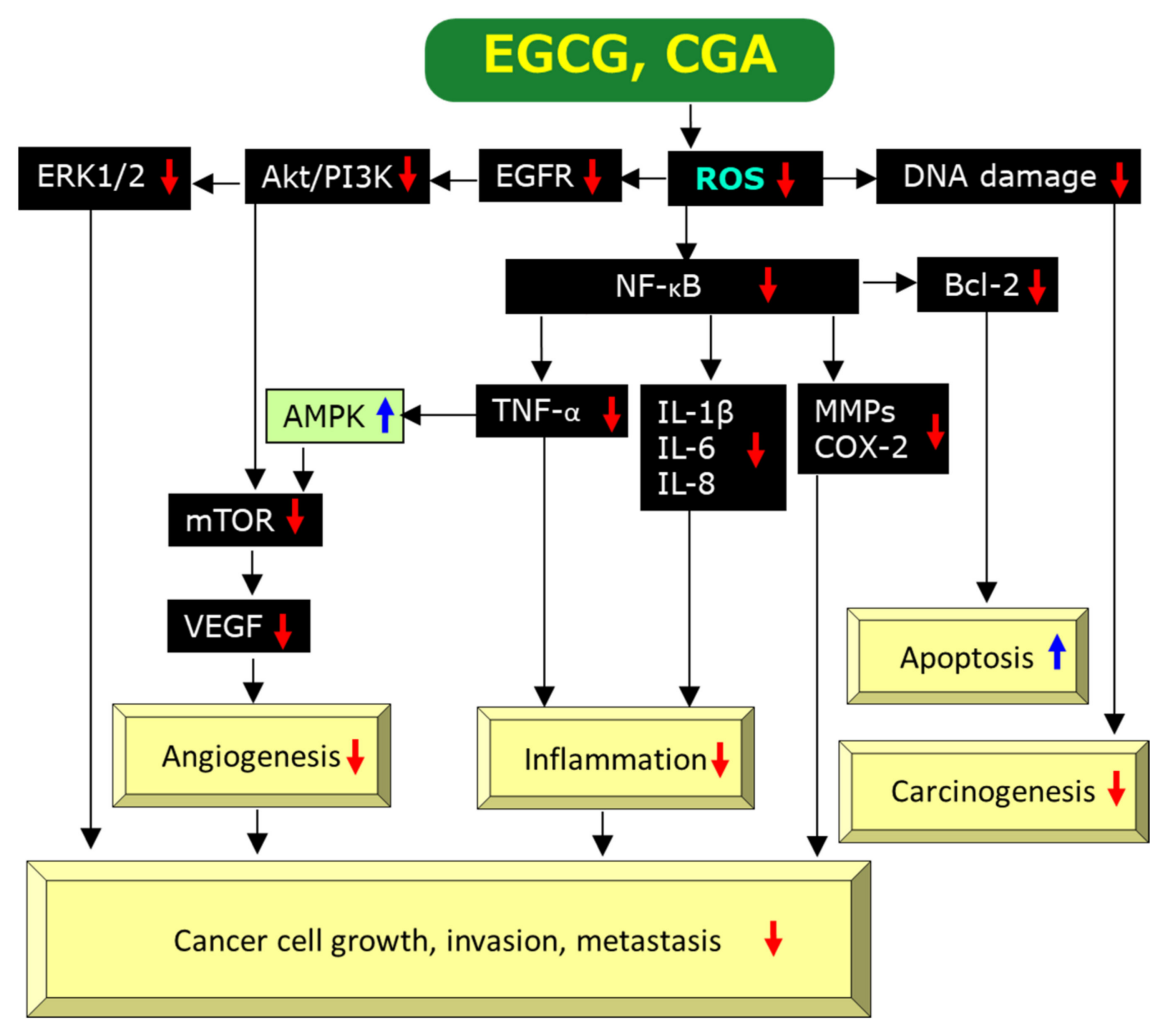

Figure 2. A possible mechanism by which EGCG and CGA exert anti-cancer effects via scavenging/downregulation of ROS. Red $\downarrow$ and blue $\uparrow$ marks represent downregulation/suppression and upregulation/stimulation, respectively.

Actually, Bulboaca, et al. showed that i.p. administration of EGCG or liposomal EGCG improved the oxidative stress parameters such as malondialdehyde levels and nitric oxide (NO) synthesis as well as those of anti-oxidant status as evaluated by total anti-oxidant capacity and levels of thiols and catalase in plasma of rats treated with streptozotocin [46].

Paradoxically, the pro-oxidant activity of EGCG has also been demonstrated by several studies and generation of ROS by EGCG is thought to be essential for the induction of apoptosis and inhibition of cell growth of cancer cells $[37,40,42,47]$, as shown in Figure 3 which is compiled on the basis of previous data [2,34,42,48-52]. Since ROS generation induced by EGCG can upregulate AMPK, presumably through upregulation of $\mathrm{Ca}^{2+} /$ calmodulin-dependent protein kinase kinase (CaMKK) and/or liver kinase B1 (LKB1) [49,50], leading to downregulation of mechanistic target of rapamycin kinase (mTOR) which results in anti-cancer effects. There are some reports to show downregulation of nuclear factor- $\mathrm{kB}(\mathrm{NF}-\mathrm{kB})$ by AMPK, if not directly [51,52]. Xiang et al. [52] demonstrated that AMPK inhibited NF- $\mathrm{BB}$ activity using mice treated with complete Freund's adjuvant. Therefore, ROS-mediated AMPK activation may also cause the downregulation of NF- $\mathrm{kB}$, leading to anti-cancer effects through induction of apoptosis (Figure 3). 


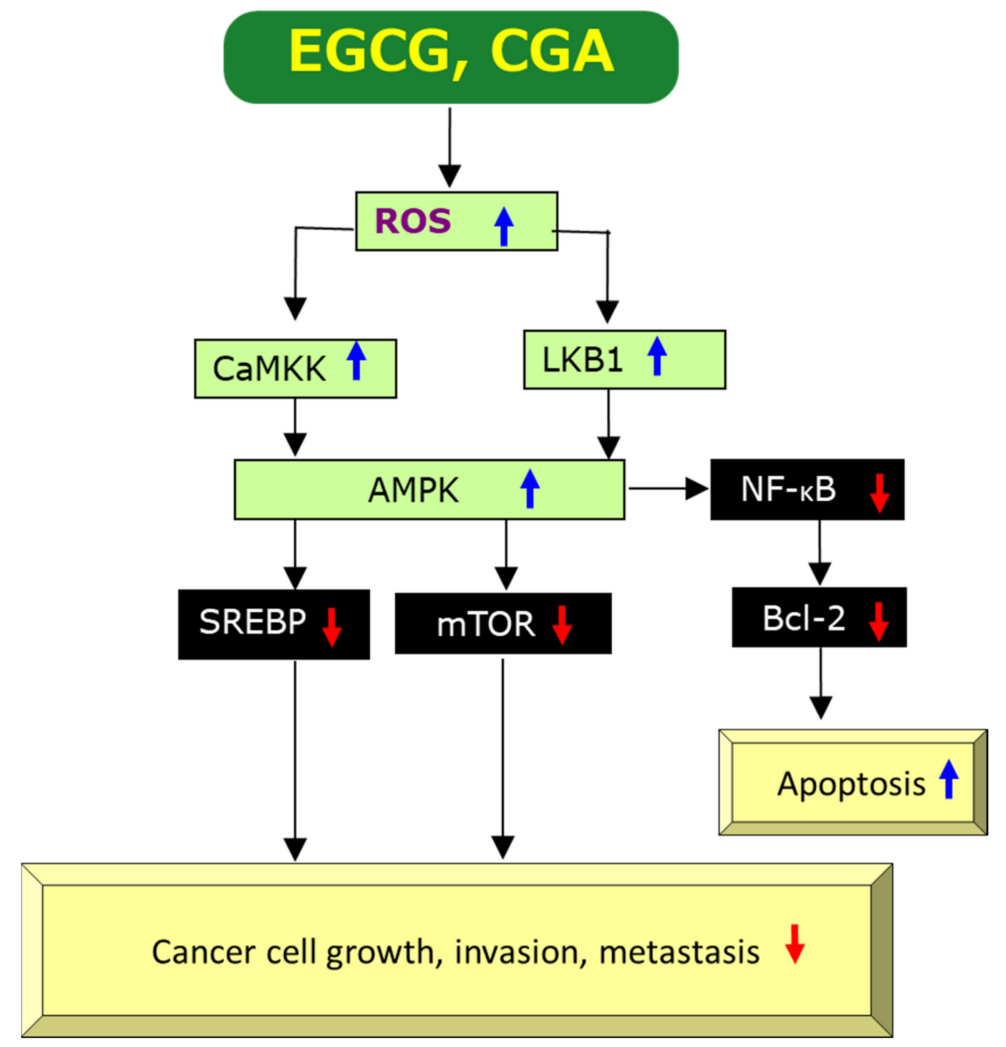

Figure 3. A possible mechanism by which EGCG and CGA exert anti-cancer effects via generation/upregulation of ROS. Red $\downarrow$ and blue $\uparrow$ marks represent downregulation/suppression and upregulation/stimulation, respectively.

However, it is not clear at present by what mechanism EGCG act's as an anti-oxidant or a pro-oxidant, although difference in cell types and different cellular concentrations including those of EGCG itself, metal ions, and the co-presence of other anti-oxidants may be important factors [42,53]. It can be assumed that either the anti-oxidant and pro-oxidant activities are involved in various mechanisms by which EGCG exerts anti-cancer effects (Figures 2 and 3).

\subsubsection{Anti-Inflammatory Effects}

Chronic inflammation is thought to have an important role on the onset and progression of human cancer by modulating the tumor microenvironment [54]. A number of studies have provided evidence EGCG's anti-inflammatory effects. These studies found that EGCG can inhibit activation of transcription factors such as NF- $\mathrm{kB}$, activating protein-1 (AP-1), MyD88-dependent signaling pathway, Toll-interleukin- 1 receptor domain-containing adaptor inducing interferon- $\beta$ (IFN- $\beta$ )-dependent signaling pathways of Toll-like receptors, and expressions of inflammatory genes including cyclooxygenase (COX), NO synthase, and TNF- $\alpha[42,43,55]$. Many of these actions may be interpreted by EGCG's anti-oxidant activity (Figure 2). For example, ROS can induce NF- $\kappa$ B activation which in turn promotes biosynthesis of COX, NO, and TNF- $\alpha$ and, therefore, scavenging ROS by EGCG would lead to its anti-cancer effects [2,42] (Figure 2).

\subsubsection{Anti-Angiogenic Effects}

Angiogenesis is the process characterized by the development of new blood vessels from the pre-existing vessels, which supply a tumor with oxygen and nutrients to allow optimal growth. Anti-angiogenesis is thought to be one of the most promising methods of cancer treatment [56]. 
Cancer cells can adopt to the hypoxic microenvironment by expressing hypoxia-inducible factors-1 (HIF-1) and thereby increasing the levels of its downstream target vascular endothelial growth factor (VEGF), which promotes tumor growth, angiogenesis, and metastasis [57-59]. EGCG was shown to decrease the protein expression of HIF-1 $\alpha$ and VEGF proteins in gastric cancer SGC7901 cells under hypoxia induced by cobalt chloride [59].

In a study in which C57BL/6J mice inoculated with $10^{6}$ mouse breast cancer E0771 cells in the mammary gland fat pad, oral intake of EGCG at $50-100 \mathrm{mg} / \mathrm{kg} /$ day for 4 weeks reduced tumor weight, capillary density and tumor VEGF expression by 65, 30 and 23\%, respectively, compared to control. EGCG at $50 \mu \mathrm{g} / \mathrm{mL}$ significantly inhibited the activation of HIF-1 $\alpha$ and NF- $\mathrm{KB}$ as well as VEGF expression in cultured E0771 cells. These findings indicate that EGCG exerts anti-cancer effect by inhibiting angiogenesis mediated by the downregulation of VEGF, HIF-1 $\alpha$ and NF-kB [60].

Wu et al. [61] found that EGCG inhibited the proliferation, viability, and cell cycle progression in three types of human thyroid carcinoma cells by decreasing the migration and invasion and increasing apoptosis. EGCG downregulated molecular signaling factors such as epidermal growth factor receptor (EGFR), extracellular signal-regulated kinase 1/2 (ERK1/2), and mitogen-activated protein kinase (MAPK) and inhibited tumor microvessel density dose-dependently in xenografts of these cells (Figure 2). Induction of angiogenesis by VEGF is caused by binding to its receptors on the surface of endothelial cells. Kondo et al. [62] reported that EGCG (1.56 to $100 \mu \mathrm{M})$ inhibited VEGF binding to its receptors in a dose-dependent manner.

Alternatively, EGCG's anti-angiogenic action may be related to its pro-oxidant activity. EGCG may induce generation of ROS to promote apoptosis which is known to be the primary action of many anti-cancer drugs. ROS can up-regulate, perhaps indirectly, AMPK which modulates expressions of a number of proteins [3]. ROS-mediated activation of AMPK can lead to downregulation of mTOR, resulting in downregulation of VEGF (Figure 3) [2,36]. Therefore, EGCG's pro-oxidant property can decrease the level of VEGF in cancer cells and tissues.

\subsubsection{Induction of Apoptosis}

Induction of apoptosis or programmed cell death is one of the most important mechanisms for EGCG to exert anti-cancer effects. Several studies have provided evidence for the induction of apoptosis by EGCG and its mechanism of action. ROS can stimulate gene expression of B-cell lymphoma-2 (Bcl-2) via activation of NF- $\mathrm{B}$ and therefore, EGCG's scavenging activity of ROS is expected to downregulate the anti-apoptotic protein Bcl-2 (Figure 2), leading to apoptotic cell death of cancer cells (Figure 2).

Meanwhile, EGCG may induce apoptosis through enhancing ROS production (Figure 3). Das et al. [63] demonstrated that EGCG induced apoptosis via triggering ROS production with phosphorylation of p38 MAPK and activation of the redox-sensitive c-Jun N-terminal kinase-1 pathway. EGCG was also found to induce overexpression of apoptosis regulator Bcl-2 associated X (Bax) and activation of calpain, caspase-9, caspase-3, and caspase-8. It is noteworthy that EGCG did not induce apoptosis in human normal astrocytes [63].

Zan, et al. [64] reported that 5 and $20 \mu \mathrm{g} / \mathrm{mL}$ of EGCG induced apoptosis in breast cancer MCF-7 cells via the activation of caspase-9, caspase-3, and poly (ADP-ribose) polymerase-1 cleavage. Kwak et al. [65] also showed that $5 \mu \mathrm{g} / \mathrm{mL}$ of EGCG caused apoptosis in human cholangiocarcinoma $\mathrm{HuCC}-\mathrm{T} 1$ cells through the increase of pro-apoptotic protein Bax and activation of caspase-9 and caspase-3, and cytochrome c release. Similarly, Jian et al. [66] found that EGCG induced apoptosis in human hepatocellular carcinoma (HCC) HepG2 cells and rat pheochromocytoma PC12 cells through downregulation of Bcl-2 and upregulation of Bax.

Sterol-response element binding protein-1 (SREBP-1), a nuclear transcription factor mainly involved in lipid metabolism, is also downregulated by AMPK (Figure 3). SREBP-1 is expressed at higher levels in patients with large tumor size, high histological grade and advanced tumor-node-metastasis stages. Downregulation of SREBP-1 inhibited cell proliferation and induced apoptosis in both HepG2 and MHCC97L cells and SREBP-1 knockdown inhibited cell migration and invasion in both cancer 
cell types [67]. Since EGCG's suppression of the expression of SREBP-1 through the activation of the AMPK pathway in sebocytes was reported [68], this EGCG's inhibition may be expected to contribute to its anti-cancer effect (Figure 3).

\subsubsection{Epigenetic Modifications}

Epigenetic modifications represent post-translational changes in histones and DNA such as methylation and acetylation as well as dysregulation of microRNAs (miRNAs) expression [69]. Noncoding RNAs (ncRNAs) consist of miRNAs and long noncoding RNAs (lncRNAs) where miRNAs are defined as small single-stranded molecules (ca. 20 to 25 nucleotides) and lncRNAs as RNA molecules larger than 200 nucleotides. These ncRNAs are implicated in various cellular processes through regulating gene expression at the transcriptional and post-transcriptional level and thought to play roles in various diseases including cancer [70].

One mechanism involved in anti-cancer effects exerted by EGCG is such epigenetic modifications. The inhibitors of DNA methyltransferase (DNMT) and histone deacetylase (HDAC) are expected to be promising anti-cancer drugs. Fang et al. [71] demonstrated that EGCG inhibited DNMT activity with a Ki of $6.89 \mu \mathrm{M}$. Similarly, Pal et al. [72] showed that $10 \mu \mathrm{g} / \mathrm{mL}$ of EGCG decreased the proliferation of HeLa cells and expression of DNMT-1. Khan et al. [73] showed that EGCG inhibited the expression of DNMT-3B and HDAC-1 in a time-dependent manner in human cervical carcinoma HeLa cells.

In a review by Aggarwal et al. [32] the authors summarized the effects of EGCG on various cancers reported in 11 studies. In an experiment using cervical carcinoma cell lines, EGCG inhibited HeLa cells growth in a dose- and time-dependent manner [74]. EGCG caused downregulation of miR-125b and upregulation of miR-210 and miR-29 in HeLa cells and also upregulation of miR-210 and miR-29 expressions in CaSKi and SiHa cells. EGCG's upregulation of miR-210 was also found in experiments using lung cancer cells and a nude mouse model [75]. Overexpression of miR-210 led to reduction in cell proliferation and anchorage-independent cell growth [75].

In addition, Aggarwal et al. [32] described three studies in which EGCG upregulated the let-7 family miRNAs, which were implicated to function as a tumor suppressor and cause down-regulation of high mobility group-A2, a target gene related to tumor progression via $67-\mathrm{kDa}$ laminin receptor (67LR)-binding in melanoma cells [76].

In another study, EGCG was demonstrated to decrease the expression of p53 gene-targeting miRNAs (miR-25, miR-92, miR-141, and miR-200a) in multiple myeloma cells [77]. The data suggest that EGCG can reverse the elevated expression of miRNAs which downregulate p53 in cancer cells and exert its anti-cancer effect via recovery of the activity of tumor suppressor $\mathrm{p} 53$. In harmony with this finding, EGCG was shown to stabilize p53 to upregulate its transcriptional activity leading to apoptosis in prostate cancer LNCaP cells [78]. It should be noted that EGCG downregulated miR-25 and miR-92 in multiple myeloma cells but upregulated them in HCC [77]. The difference may be due to cell-specific effect but further studies are required to understand the EGCG's effects on miRNAs.

$\mathrm{Hu}$ et al. [79] demonstrated that EGCG inhibited the growth of lung cancer A549 and NCI-H460 cells in a concentration-dependent manner. They identified an upregulation of RP1-74M1.3, AC087273.2, SNAI3-AS1, LINC02532, and AC007319.1 lncRNAs and downregulation of HMMR-AS1, AL392089.1, PSMC3IP, LINC02643, and H19 lncRNAs in EGCG-treated A549 cells. These lncRNAs are distributed across nearly all human chromosomes and EGCG affected lncRNAs expressions, suggesting that EGCG can regulate the expression of ncRNAs to exert anti-cancer activity in several types of cancer.

\subsubsection{Molecular Docking Analysis of EGCG's Binding to Cancer-Related Proteins}

A number of studies have demonstrated that the binding affinity of EGCG to proteins contributes to its anti-cancer mechanism. There are several physicochemical methods to examine molecular interaction between EGCG and proteins. In 1997, our research group conducted for the first time affinity chromatography using EGCG-agarose gel to demonstrate that EGCG binds to matrix metalloproteinase (MMP)-2 and MMP-9 which are intimately associated with cancer cell invasion and metastasis [80]. 
EGCG inhibited activities of these enzymes, leading to anti-cancer effects like batimastat (BB-94), a synthetic MMP inhibitor that inhibits tumor growth, local invasion, and lung metastasis of orthotopic metastatic human HCC in nude mice model [80,81]. Later, the binding interaction between EGCG and MMP-2 and MMP-9 was confirmed by computational molecular docking analysis (MDA) [82].

In our previous review article, we discussed binding interactions between EGCG and other cancer-related proteins revealed by affinity chromatography and pull-down methods using EGCG-agarose gel [82]. These include fibronectin, vimentin, heat shock protein 90, glucose-regulated protein 78 kDa (GRP78), insulin-like growth factor-1 receptor, Src-related proto-oncogene Fyn protein, $\zeta$ chain-associated 70-kDa protein, Ras-GTPase-activating protein Src homology (SH3) domain-binding protein-1, peptidyl-prolyl cis-transisomerase, and TNF receptor-associated factor-6. Most of these interactions were confirmed by MDA [82].

Similarly MDA revealed the binding interaction between EGCG and VEGF, VEGF receptors, tyrosine kinases, urokinase, chymotrypsin, DNMT, protein phosphatases, and signal transducer and activator of transcription-3 [83]. These protein-binding interactions are likely to be involved in EGCG's anti-cancer effects.

\subsubsection{Roles of 67LR in EGCG's Anti-Cancer Effects}

One of the EGCG's most important interactions may be that with 67LR, which was discovered by a surface plasmon resonance technique as discussed in several papers [84-86]. EGCG was shown to bind 67LR at physiologically available concentrations (0.1-1.0 $\mu \mathrm{M})$ and to mediate many of its beneficial activities, including anti-cancer effect. EGCG binding to 67LR via eukaryotic elongation factor-1A causes the phosphorylation of myosin phosphatase targeting subunit- 1 and activates myosin phosphatase which dephosphorylates its substrates such as myosin regulatory light chain, resulting in actin cytoskeleton rearrangement leading to cell growth inhibition $[84,86]$.

\section{Anti-Cancer Effects of Coffee}

\subsection{Human Studies on Anti-Cancer Effects of Coffee}

Coffee is the second most consumed beverage worldwide after tea. Some early epidemiological studies suggested that coffee consumption was associated with an increased cancer risk [87]. For example, Yu et al. [88] described that daily coffee consumption is a risk factor in females for renal cell carcinoma. Based on the results of 32 epidemiological studies, Wierzejska found that several studies showed that coffee consumption had no or even unfavorable association with colorectal, breast, bladder, prostate, lung and pancreatic cancers, but emphasized that other studies showed promising results for these cancers and liver cancer [87].

Several early RCT suggested the coffee's favorable effects on cancers as exemplified by following findings: When 64 participants were randomly assigned into two groups and consumed $1000 \mathrm{~mL}$ of cafetière coffee daily or no coffee for intervention and washout periods, the result indicated that unfiltered coffee significantly increased the glutathione content by $8 \%$ in the colorectal mucosa and by $15 \%$ in plasma [89]. The increase in the detoxification capacity and anti-mutagenic properties in the colorectal mucosa through an increase in glutathione concentration suggests the possible lowering effect on the colon cancer risk [89].

A clinical trial with 10 participants found that consumption of $1 \mathrm{~L}$ unfiltered coffee/day over 5 days resulted in a weak induction of glutathione-S-transferases (GSTs) and 3-fold increase in induction of placental type GST in blood, although other clinical markers for organ damage such as creatinine, aminotransferases, and alkaline phosphatase were not altered [90]. The finding suggests that coffee's induction of placental type GST may lead to protection from chemical carcinogenesis.

In a controlled intervention trial with a cross-over design with 38 participants, consumption of $800 \mathrm{~mL}$ coffee daily over 5 days demonstrated the decrease by $12.3 \%$ in the extent of DNA-migration attributable to formation of oxidized purines, although other biochemical parameters such as the total 
anti-oxidant levels in plasma, glutathione concentrations in blood, and the activities of superoxide dismutase and glutathione peroxidase in lymphocytes were not markedly altered. The result indicates that coffee consumption prevents endogenous formation of oxidative DNA-damage in human [91].

Recent evidence has also suggested that coffee drinking may have health benefits on some types of cancer. A review by an International Agency for Research on Cancer working group conducted in 2016 on a large number of epidemiological and experimental studies on anti-cancer effects of coffee found an inverse association for liver and endometrial cancers [92].

Similarly, a comprehensive review of the beneficial effects of coffee and its components on gastrointestinal and liver carcinogenesis summarized observational epidemiological studies: four studies on oropharyngeal cancer, four on esophagus cancer, four on stomach cancer, four on CRC, and seven HCC [11]. Comparing the highest and lowest consumptions, all study results showed 31-37\% risk reduction in oropharyngeal cancer, no risk reduction in esophagus cancer, no risk reduction in CRC and 34-43\% risk reduction in HCC, although some subgroup analyses gave different results. In the case of stomach cancer, one study found reduced risk, two no effect and one increased risk. These results indicate that the coffee's benefit might be limited to liver cancer.

In addition, a recent meta-analysis of observational studies on associations between coffee intake and 26 different cancers including 364,749 cancer cases provided evidence to show that coffee intake is inversely associated with endometrial cancer, liver cancer, melanoma, oral cancer, and oral/pharyngeal cancer [93]. Additional evidence was also obtained to suggest the reduced risk of cancers of the mouth, pharynx and larynx, and skin cancer. Coffee consumption may also be inversely associated with breast, colon, colorectal, esophageal and nonmelanoma skin cancers.

Conversely, the same analysis showed the conflicting result whereby a higher coffee intake was associated with an increased risk of childhood acute lymphocytic leukemia, bladder cancer, and possibly lung cancer [93]. Similarly, a more recent pooled analysis of 12 cohort studies, comprising of 2601 cases out of 501,604 participants found a significantly increased risk for bladder cancer in male smokers: when compared the consumers of $>4$ cups/day with the non-consumers, hazard ratios were 1.75 ( $\mathrm{CI}=1.27-2.42)$ for current smokers and 1.44 (CI = 1.12-1.85) for former smokers [94].

In a review on the association of CRC risk with coffee, caffeinated coffee and decaffeinated consumptions, Buldak et al. [10] discussed eight, seven and three observational epidemiological studies showing no association, inverse association, and association with increased risk, respectively. These authors pointed out that caffeine is not an important component for coffee to exhibit the anti-cancer activity, since several studies found significant inverse correlation for both caffeinated and decaffeinated coffee consumptions.

A recent RCT on 160 healthy human subjects who consumed 3 or 5 cups of coffee per day for 8 weeks found that blood pressure, oxidation of DNA and lipids, blood levels of glucose, insulin, cholesterol, triglycerides, and inflammatory markers were unchanged, although a slight elevation of serum creatinine level and a significant elevation of serum $\gamma$-glutamyltransaminase levels in the 5 cups/day group [95]. The results indicated no detectable effects, either beneficial or harmful, on human health.

Thus, these findings from clinical studies are conflicting. The recall bias and confounding effects including tobacco smoking, a method for brewing coffee, differences in ingredients, and genetic background may contribute to these differences.

\subsection{Comparison of Anti-Cancer Effects of Tea and Coffee in Simultaneous Human Studies}

Several epidemiological studies have examined the anti-cancer effects of tea and coffee at the same time. For example, the European Prospective Investigation into Cancer and Nutrition on 486,799 subjects with a median follow-up of 11 years found that both coffee and tea intakes were inversely associated with HCC risk. Coffee and tea consumers in the highest compared to the lowest quintile had lower HCC risk by $72 \%$ and 59\%, respectively [96]. In a study in which 10,399 of total 97,334 subjects developed cancers of 145 head and neck, 99 oesophageal, 136 stomach, 1137 lung, 1703 breast, 
257 endometrial, 162 ovarian, 3037 prostate, 318 kidney, 398 bladder, 103 gliomas, and 106 thyroid, tea consumption of $\geq 1$ cups/day was inversely associated with cancer overall combined ( $R R=0.95$, $\mathrm{CI}=0.94-0.96$ ) as compared to $<1$ cup consumption, but no association of coffee consumption with the risk of all cancers combined was found. However, coffee intake decreased a risk for endometrial cancer $(\mathrm{RR}=0.69,95 \% \mathrm{CI}=0.52-0.91$ for $\geq 2$ cups per day), while tea did not [97].

A meta-analysis of 12 case-control studies, comprising a total of 3649 cases and 5705 controls found that a high maternal coffee consumption increased a risk of acute lymphoblastic leukemia in childhood ( $\mathrm{OR}=1.43)$, whereas low to moderate tea consumption was inversely associated (odds ratio $(\mathrm{OR})=0.85, \mathrm{CI}=0.75-0.97)$, although the trend was not significant [98].

Table 2 shows a brief comparison of anti-cancer effects of tea and coffee in simultaneous studies reported since 2018 based on the Medline data base. Several investigations revealed that tea and coffee may have different effects in some cancer types. It is noticeable that coffee may increase a risk in certain types of cancer (bladder cancer, lung cancer, and childhood leukemia) in line with the finding from aforementioned studies which examined effects of either tea or coffee, individually [93].

Table 2. Comparison of anticancer effects in humans between tea and coffee.

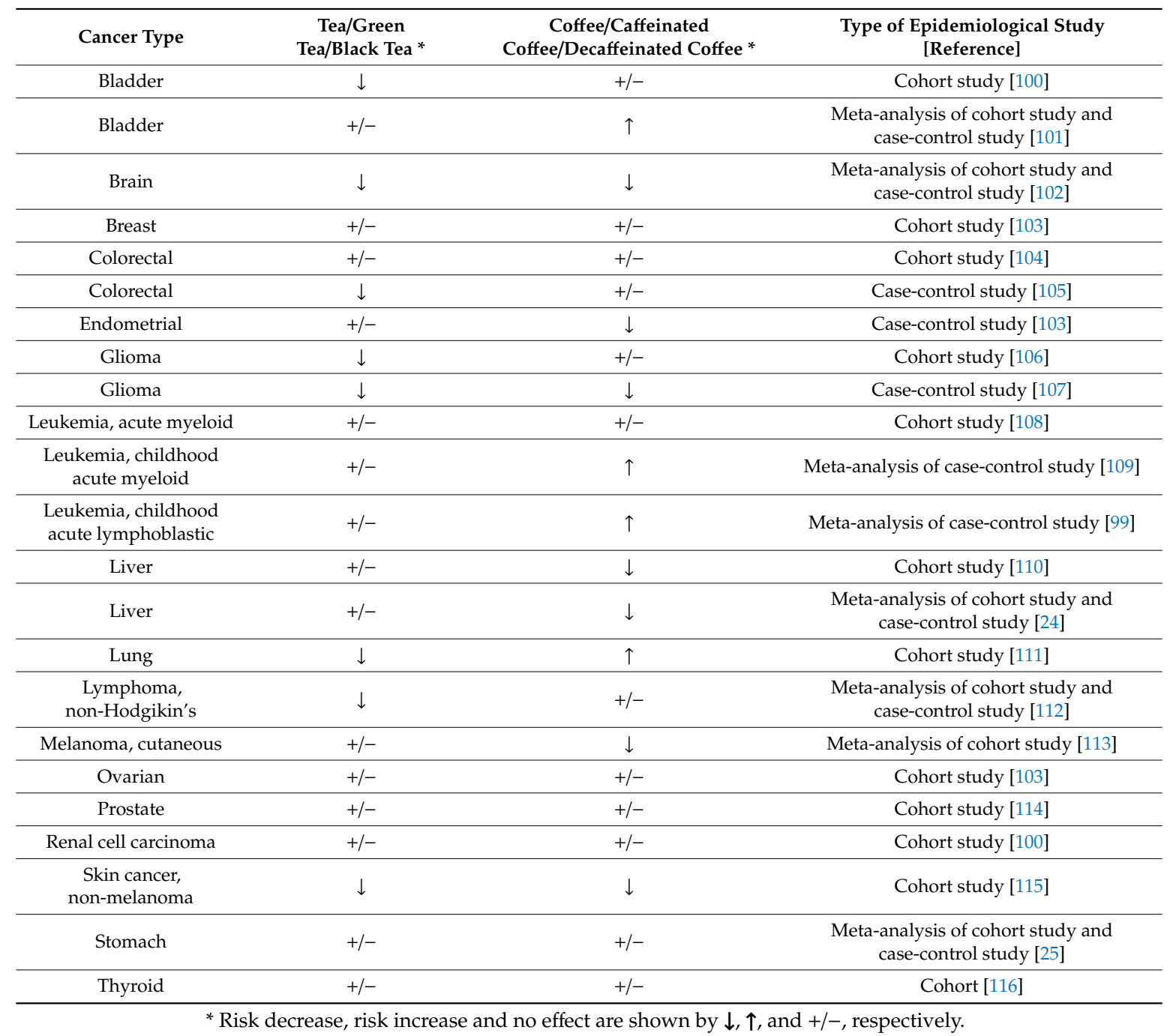

The reason for the difference is not known at present. As pointed out by Milne et al. [99], the fact that both tea and coffee contain numerous different compounds, are prepared by various methods, and have differences in bioavailability makes it difficult to determine the factor(s) involved in the difference. 


\subsection{Basic Research on Anti-Cancer Action of Coffee and CGA}

A number of cell-based and animal studies have provided evidence to support anti-cancer effects of coffee and CGA [117-120]. Salomone et al. [118] have elegantly discussed molecular basis of anti-cancer effects of coffee and some of its components including CGA. They summarized the results of 10 animal studies showing anti-cancer effects of coffee and CGA as examined in experimental models of liver cancer. For example, in an experiment of Miura et al. [119] coffee inhibited the proliferation and invasion of rat ascites hepatoma AH109A cells and the serum from rats given coffee orally also exhibited anti-proliferative and anti-invasive activities against these cells.

Similarly, Buldak et al. [10] reviewed the human and basic studies on anti-cancer effects of coffee and its components on CRC. These authors discussed the results of three cell-based studies on CGA. In an experiment by Hou et al. [120], CGA was shown to inhibit the proliferation of human colon cancer HCT116 and HT29 cells. CGA induced ROS generation and cell cycle arrest at the S phase, and suppressed the activation of ERK in both cell types, leading to the anti-cancer effect against CRC.

More recently, Romualdo et al. [11] discussed these issues on the basis of animal studies of the effects of coffee and CGA on oral and esophagus cancers (four studies), colon cancer (nine studies) and HCC (four studies). For example, the included data showed that two of four studies of coffee and four of five studies of CGA demonstrated beneficial effects on colon cancer. These authors summarized the mechanistic aspects of CGA's action which are associated with molecular pathways involving ROS and others such as Bax, interleukin (IL)-8, caspase-3, MMPs and miR-21. Although these articles also reviewed comprehensively other coffee components such as caffeine, caffeic acid, and kahweol, this review focuses CGA which is considered to be the major player in the coffee's anti-cancer mechanism as discuss below.

\subsection{Mechanisms of CGA's Action against Cancer}

3.4.1. Anti-Oxidant and Pro-Oxidant Properties, Anti-Inflammatory Effects, Anti-Angiogenic Effects and Apoptosis-Inducing Activity of CGA

CGA's involvement in anti- and pro-oxidant actions, anti-inflammatory effects, anti-angiogenic effects, and apoptosis-inducing activity of coffee has often been documented [7,11,48,118,120-122]. Examples are as follows:

Cha et al. [123] demonstrated that UVB gave damage to cellular DNA in human HaCaT cells, as demonstrated in a comet assay, but CGA pre-treatment prior to UVB irradiation prevented oxidative DNA damage and increased cell viability. Rakshit et al. [124] found that CGA induced an early accumulation of intracellular ROS and apoptosis in chronic myeloid leukemia cells.

Feng et al. [121] found that CGA inhibited the proliferation of A549 human cancer cells in vitro and that CGA suppressed 12-O-tetradecanoylphorbol-13-acetate (TPA)-induced neoplastic transformation of JB6 P+ cells. CGA decreased UVB- or TPA-induced transactivation of AP-1 and NF- $\kappa B$, the phosphorylation of c-Jun $\mathrm{NH}_{2}$-terminal kinases, p38 kinase, and MAPK kinase- 4 induced by UVB or TPA. The results also showed that CGA stimulated the nuclear translocation of NF-E2-related factor (Nrf2) as well as subsequent induction of GST-A1 anti-oxidant response element (ARE)-mediated GST activity. These results suggest that the chemopreventive effects of CGA may be through its up-regulation of cellular anti-oxidant enzymes via stimulation of Nrf2 and suppression of ROS-mediated NF- $\mathrm{kB}$, AP-1, and MAPK activation [121].

Liang and Kitts reviewed anti-oxidative and anti-inflammatory effects of CGA [122]. They discussed five cell-based studies and two animal experiments, in which downregulation of ROS was demonstrated, and 10 experiments, most of which showed downregulation of inflammation-related cytokines such as IL-1 $\beta$, TNF- $\alpha$ and IL-6. Four such studies revealed downregulation of NF- $\mathrm{kB}$.

When anti-inflammatory effect of CGA was examined in lipopolysaccharide-stimulated murine RAW 264.7 macrophages and BV2 microglial cells, CGA inhibited NO production, the expression of 
COX- 2 and inducible NO synthase, and attenuated pro-inflammatory cytokines such as IL-1 $\beta$ and TNF- $\alpha$ via inhibition of the nuclear translocation of NF-kB [125].

In an attempt to evaluate the effects of CGA on retinal neovascularization in a mouse model of oxygen-induced retinopathy, Kim et al. [126] found that CGA inhibited VEGF-mediated tube formation in human vascular endothelial cells and that the neovascular area was significantly smaller in CGA-treated mice than in the vehicle-treated mice, demonstrating the CGA's anti-angiogenic property.

Most of these results are related to modulation of ROS and the aforementioned mechanisms by which EGCG exerts its anti-cancer effects might be applicable to CGA. Figures 2 and 3 show possible modulations by CGA, although individual pathways in which CGA is involved have not necessarily been reported. Figure 2 illustrates CGA's downregulation of ROS [2,11,48,120,127], DNA damage [123], EGFR [127], Akt/phosphatidyl3-inositol kinase (PI3K) [127], ERK1/2 [11,127], NF-kB [2,121,125,127,128], TNF- $\alpha$ [2,122], IL-1 $\beta$ [122], IL-8 [2,11], IL-6 [122], MMPs [2,11], COX-2 [125,128], Bcl-2 [10,129], mTOR [10,127], VEGF [126], and upregulation of AMPK [7,49]. Although CGA's upregulation of CaMKK and LKB1 shown in Figure 3 has not been determined yet, Park et al. [130] reported upregulation of them by neochlorogenic acid, an isomer of CGA. Thus, EGCG and CGA would be expected to exert anti-cancer effects by modulating similar molecular pathways to each other in many cases.

\subsubsection{Epigenetic Modification by CGA}

Increased levels or alterations in the function of DNMT-1 are associated with the inactivation of tumor suppressor genes. Liu et al. [131] showed that CGA inhibited the proliferation, colony formation, invasion, and metastasis of HepG2 cells both in vitro and in vivo by down-regulating DNMT-1 protein expression, which enhanced p53 and p21 activity, and resulting in a significant reduction in cell proliferation and metastasis. Moreover, CGA inactivated ERK1/2 and reduced MMP-2 and MMP-9 expression in HepG2 cells. These findings suggest that CGA exhibits anti-cancer effects through several pathways. Using synthetic DNA substrates, Lee and Zhu found that CGA inhibited human DNMT-1 activity with an $\mathrm{IC}_{50}$ value of $0.9 \mu \mathrm{M}$. In MCF-7 and MAD-MB-231 human breast cancer cells, CGA inhibited the methylation of the promoter region of the retinoic acid receptor $\beta$ gene [132].

Mira and Shimizu found the methanol extract of the medical herb Angelica shikokiana and some of its components including CGA showed cytotoxicity against various cultured cells and inhibited tubulin polymerization [133]. CGA was shown to inhibit activity of HDAC-8 $\left(\mathrm{IC}_{50}=8.62 \mu \mathrm{M}\right)$.

Hongtao et al. [134] found that CGA blocked the proliferation of non-small cell lung cancer cells. CGA inhibited HDAC-6 and MMP-2 activities through reduction in expression of acetylated NF- $\mathrm{kB}$, the level of which is positively associated with the transcription of pro-inflammatory cytokines [134]. The results suggest CGA's anti-cancer effect through suppression of HDAC-6 activity. In line with these findings, an inhibition experiment with HeLa cell nuclear extracts and MDA conducted by Bora-Tatar et al. [135] demonstrated that CGA is the highly potent inhibitor compared to sodium butyrate, which is a well-known HDAC inhibitor.

Several studies have examined effects of CGA on miRNAs. The results of a study, in which hepatic stellate $\mathrm{LX} 2$ cells and $\mathrm{CCl}_{4}$-induced liver fibrosis model rats are used, indicated that CGA inhibited the mRNA expression of miR-21, Smad7, connective tissue growth factor, $\alpha$-smooth muscle actin, tissue inhibitor of metalloproteinase 1, MMP-9, and transforming growth factor- $\beta 1$ (TGF- $\beta 1$ ), suggesting that CGA relieves liver fibrosis through the miR-21-regulated TGF- $\beta 1 / \mathrm{Smad} 7$ signaling pathway [136]. Similar results were reported by Wang et al. [137] who showed that CGA could inhibit schistosomiasis-induced liver fibrosis through IL-13/miR-21/Smad7 signaling interactions in LX2 cells and schistosome-infected mice. Since liver fibrosis is a key factor for the risk of HCC [138], CGA might be useful for its prevention.

Induction of cancer differentiation may be a promising strategy to treat cancer. CGA reduced proliferation rate and migration/invasion ability in human hepatoma Huh7 and lung H446 cancer cells through elevation of small ubiquitin like modifier- 1 expression by acting on its $3^{\prime}$-untranslated region and stabilizing the mRNA, leading to downregulation of miR-17 family member miR-20a, -93, 
and -106b. The xenograft experiments using these cells gave similar results. NOD/SCID mice which received i.p. administration of $25-200 \mathrm{mg} / \mathrm{kg} /$ day of CGA demonstrated tumor growth inhibition and administration of $25 \mathrm{mg} / \mathrm{kg}$ caused downregulation of miR-17 family members [139].

\subsubsection{MDA of CGA's Binding to Cancer-Related Proteins}

The results of MDA showed that quercetin, rutin, and CGA can bind to MMP-1, MMP-3, and MMP-10 [140]. MDA of CGA and carbonic anhydrase IX showed the high affinity which is attributable to the strong interaction with enzyme active site through the formation of eight hydrogen bonds with the active site residue [141].

MDA for natural products which may interfere with SARS-CoV-2 attachment to the host cell found that CGA had the good average binding affinity to the cell-surface heat shock protein A5 (GRP78) of $-7.10 \pm 0.96 \mathrm{kcal} / \mathrm{mol}[142]$.

P-glycoprotein is associated with multidrug resistance as a drug efflux protein. CGA exhibited anti-proliferative effect on the mouse T-cell lymphoma L5178 cells with an $\mathrm{IC}_{50}=0.06 \pm 0.003 \mu \mathrm{g} / \mathrm{mL}$ and reversed multidrug resistance. MDA revealed that CGA can bind to three different sites which are known to be bound by verapamil with similar binding energies of around $7 \mathrm{kcal} / \mathrm{mol}$ [143].

CGA induced apoptosis in a dose-dependent manner with an $\mathrm{IC}_{50}$ of $75.88 \pm 4.54 \mu \mathrm{g} / \mathrm{mL}$ and $52.5 \pm 4.72 \mu \mathrm{g} / \mathrm{mL}$ in MDAMB-231 and MCF-7 cells, respectively. CGA binds to protein kinase C in a concentration-dependent manner with a $\mathrm{Kd}$ of $28.84 \pm 3.95 \mu \mathrm{M}$ and MDA suggested that CGA fits into the $\mathrm{C} 1 \mathrm{~b}$ domain of protein kinase $\mathrm{C}$ [144].

By UPLC-MS/MS analysis, Taha et al. [145] identified 22 compounds in the extracts of the fruits of Nandina domestica Thunb. which have served as a folk medicine in therapies of some types of cancer. MDA of CGA and some other compounds revealed strong interactions with the cancer-related proteins Akt1, caspase-3, MAPK-1 and tumor suppressor TP53.

\section{Conclusions}

The present review has discussed the anti-cancer effects of green tea and coffee based on epidemiological and intervention studies. These studies have provided evidence to show favorable effects on some types of cancer such as breast, colon, lung and blood cancers by green tea consumption (Tables 1 and 2) and those such as liver, endometrial, and skin cancers by coffee consumption (Table 2). Thus, green tea and coffee are likely to have some differences in site-specific anti-cancer effects.

Meanwhile, considerable studies have reported conflicting results, presumably due to confounding factors such as the method of quantifying consumption, beverage temperature, cigarette smoking, alcohol consumption, and differences in genetic and environmental factors such as race, sex, and age, lifestyle, intestinal microbiota and genetic polymorphisms [2,34,42]. Therefore, more rigorous human studies are necessary to establish the anti-cancer effects of consumption of these beverages.

This review has also provided evidence to show anti-cancer effects of EGCG and CGA based on cellular and animal experiments. These experiments have proposed several mechanisms through which EGCG and CGA exert their anti-cancer effects. Among them, the mechanism involving downregulation of ROS appears to explain commonly their anti-cancer actions (Figure 2). Another important mechanism may be related to ROS generation as shown in Figure 3.

Meanwhile, interpretations for the different anti-cancer effects between green tea and coffee need to be clarified. One possible explanation is the difference in interaction with target molecules. For example, binding interaction has not been reported between CGA and 67LR that is an important target of EGCG. The difference in co-existing molecules may also contribute to the different effects. For example, animal experiments showed that caffeic acid present in coffee exhibited carcinogenicity in the rat stomach $[146,147]$ which may cancel the CGA's anti-cancer effect. Differences in by-products such as acrylamide generated during roasting and brewing and heavy metals and aflatoxin A which may have contaminated can be a reason $[11,22,89]$. 
In addition, some studies suggested a risk increase in certain types of cancers such as esophageal and gynecological cancers in green tea consumption [14] and bladder and lung cancers in coffee consumption (Table 2). The reason for these observations may be clarified in future studies.

Author Contributions: S.H. Corresponding author, Literature search, Text preparation of Section 3, Preparation of References; Y.O. Preparation of Abbreviations, Drawing of Figures 1-3; T.O. Literature search, Text preparation of Section 2; N.M. Literature search, Preparation of Tables 1 and 2; Y.N. Literature search, Text preparation of Section 4; M.I. Corresponding author, Project design, Outline of the whole manuscript, Literature search, Text preparation of Abstract and Introduction. All authors have read and agreed to the published version of the manuscript.

Funding: This research was funded in part by the Consignment Project of Economy and Industry Department of Shizuoka Prefecture Government (to Y.N.).

Conflicts of Interest: The authors declare no conflict of interest.

\section{References}

1. Suzuki, T.; Miyoshi, N.; Hayakawa, S.; Imai, S.; Isemura, M.; Nakamura, Y. Health benefits of tea consumption. In Beverage Impacts on Health and Nutrition; Springer International Publishing: Cham, Switzerland, 2016; pp. 49-67. ISBN 978-3-319-23672-8.

2. Hayakawa, S.; Oishi, Y.; Tanabe, H.; Isemura, M.; Suzuki, Y. Tea, Coffee and Health Benefits. In Bioactive Molecules in Food; Mérillon, J.-M., Ramawat, K.G., Eds.; Springer International Publishing: Cham, Switzerland, 2018; pp. 1-58. ISBN 978-3-319-78029-0.

3. Yang, C.S.; Zhang, J.; Zhang, L.; Huang, J.; Wang, Y. Mechanisms of body weight reduction and metabolic syndrome alleviation by tea. Mol. Nutr. Food Res. 2016, 60, 160-174. [CrossRef] [PubMed]

4. Tanaka, T.; Matsuo, Y.; Kouno, I. Biochemical and physicochemical characteristics of green tea polyphenols. In Green Tea Polyphenols; CRC Press: Boca Raton, FL, USA, 2013; pp. 19-38.

5. Cavalli, L.; Tavani, A. Coffee consumption and its impact on health. In Beverage Impacts on Health and Nutrition; Springer International Publishing: Cham, Switzerland, 2016; pp. 29-47.

6. Cano-Marquina, A.; Tarín, J.J.; Cano, A. The impact of coffee on health. Maturitas 2013, 75, 7-21. [CrossRef] [PubMed]

7. Santana-Gálvez, J.; Cisneros-Zevallos, L.; Jacobo-Velázquez, D.A. Chlorogenic acid: Recent advances on its dual role as a food additive and a nutraceutical against metabolic syndrome. Molecules 2017, 22, 358. [CrossRef] [PubMed]

8. Naveed, M.; Hejazi, V.; Abbas, M.; Kamboh, A.A.; Khan, G.J.; Shumzaid, M.; Ahmad, F.; Babazadeh, D.; FangFang, X.; Modarresi-Ghazani, F.; et al. Chlorogenic acid (CGA): A pharmacological review and call for further research. Biomed. Pharmacother. 2018, 97, 67-74. [CrossRef] [PubMed]

9. Temple, J.L.; Bernard, C.; Lipshultz, S.E.; Czachor, J.D.; Westphal, J.A.; Mestre, M.A. The safety of ingested caffeine: A comprehensive review. Front. Psychiatry 2017, 8, 80. [CrossRef] [PubMed]

10. Bułdak, R.J.; Hejmo, T.; Osowski, M.; Bułdak, Ł.; Kukla, M.; Polaniak, R.; Birkner, E. The impact of coffee and its selected bioactive compounds on the development and progression of colorectal cancer in vivo and in vitro. Molecules 2018, 23, 3309. [CrossRef] [PubMed]

11. Romualdo, G.R.; Rocha, A.B.; Vinken, M.; Cogliati, B.; Moreno, F.S.; Chaves, M.A.G.; Barbisan, L.F. Drinking for protection? Epidemiological and experimental evidence on the beneficial effects of coffee or major coffee compounds against gastrointestinal and liver carcinogenesis. Food Res. Int. 2019, 123, 567-589. [CrossRef]

12. Cui, W.-Q.; Wang, S.-T.; Pan, D.; Chang, B.; Sang, L.-X. Caffeine and its main targets of colorectal cancer. World J. Gastrointest. Oncol. 2020, 12, 149-172. [CrossRef]

13. Yang, C.S.; Hong, J. Prevention of chronic diseases by tea: Possible mechanisms and human relevance. Annu. Rev. Nutr. 2013, 33, 161-181. [CrossRef]

14. Filippini, T.; Malavolti, M.; Borrelli, F.; Izzo, A.A.; Fairweather-Tait, S.J.; Horneber, M.; Vinceti, M. Green tea (Camellia sinensis) for the prevention of cancer. Cochrane Database Syst. Rev. 2020, 3, CD005004. [CrossRef]

15. Zhang, D.; Nichols, H.B.; Troester, M.; Cai, J.; Bensen, J.T.; Sandler, D.P. Tea consumption and breast cancer risk in a cohort of women with family history of breast cancer. Int. J. Cancer 2020, 147, 876-886. [CrossRef] [PubMed]

16. Wang, Y.; Zhao, Y.; Chong, F.; Song, M.; Sun, Q.; Li, T.; Xu, L.; Song, C. A dose-response meta-analysis of green tea consumption and breast cancer risk. Int. J. Food Sci. Nutr. 2020, 71, 656-667. [CrossRef] [PubMed] 
17. Yu, S.; Zhu, L.; Wang, K.; Yan, Y.; He, J.; Ren, Y. Green tea consumption and risk of breast cancer: A systematic review and updated meta-analysis of case-control studies. Med. Baltim. 2019, 98, e16147. [CrossRef] [PubMed]

18. Wada, K.; Oba, S.; Tsuji, M.; Goto, Y.; Mizuta, F.; Koda, S.; Uji, T.; Hori, A.; Tanabashi, S.; Matsushita, S.; et al. Green tea intake and colorectal cancer risk in Japan: The Takayama study. Jpn. J. Clin. Oncol. 2019, 49, 515-520. [CrossRef]

19. Rafieian, N.; Azimi, S.; Manifar, S.; Julideh, H.; ShirKhoda, M. Is there any association between green tea consumption and the risk of head and neck squamous cell carcinoma: Finding from a case-control study. Arch. Oral Biol. 2019, 98, 280-284. [CrossRef]

20. Takada, M.; Yamagishi, K.; Iso, H.; Tamakoshi, A. Green tea consumption and risk of hematologic neoplasms: The Japan collaborative cohort study for evaluation of cancer risk (JACC Study). Cancer Causes Control 2019, 30, 1223-1230. [CrossRef]

21. Abe, S.K.; Saito, E.; Sawada, N.; Tsugane, S.; Ito, H.; Lin, Y.; Tamakoshi, A.; Sado, J.; Kitamura, Y.; Sugawara, Y.; et al. Green tea consumption and mortality in Japanese men and women: A pooled analysis of eight population-based cohort studies in Japan. Eur. J. Epidemiol. 2019, 34, 917-926. [CrossRef]

22. Xu, X.-Y.; Zhao, C.-N.; Cao, S.-Y.; Tang, G.-Y.; Gan, R.-Y.; Li, H.-B. Effects and mechanisms of tea for the prevention and management of cancers: An updated review. Crit. Rev. Food Sci. Nutr. 2020, 60, 1693-1705. [CrossRef]

23. Paul, P.; Koh, W.-P.; Jin, A.; Michel, A.; Waterboer, T.; Pawlita, M.; Wang, R.; Yuan, J.-M.; Butler, L.M. Soy and tea intake on cervical cancer risk: The Singapore Chinese health study. Cancer Causes Control 2019, 30, 847-857. [CrossRef]

24. Tanaka, K.; Tamakoshi, A.; Sugawara, Y.; Mizoue, T.; Inoue, M.; Sawada, N.; Matsuo, K.; Ito, H.; Naito, M.; Nagata, C.; et al. Coffee, green tea and liver cancer risk: An evaluation based on a systematic review of epidemiologic evidence among the Japanese population. Jpn. J. Clin. Oncol. 2019, 49, 972-984. [CrossRef]

25. Poorolajal, J.; Moradi, L.; Mohammadi, Y.; Cheraghi, Z.; Gohari-Ensaf, F. Risk factors for stomach cancer: A systematic review and meta-analysis. Epidemiol. Health 2020, 42, e2020004. [CrossRef] [PubMed]

26. Miyoshi, N.; Tanabe, H.; Suzuki, T.; Saeki, K.; Hara, Y. Applications of a standardized green tea catechin preparation for viral warts and humanpapilloma virus-related andunrelated cancers. Molecules 2020, 25, 2588. [CrossRef] [PubMed]

27. Tzellos, T.G.; Sardeli, C.; Lallas, A.; Papazisis, G.; Chourdakis, M.; Kouvelas, D. Efficacy, safety and tolerability of green tea catechins in the treatment of external anogenital warts: A systematic review and meta-analysis. J. Eur. Acad. Dermatol. Venereol. 2011, 25, 345-353. [CrossRef] [PubMed]

28. Stockfleth, E.; Meyer, T. The use of sinecatechins (polyphenon E) ointment for treatment of external genital warts. Expert Opin. Biol. Ther. 2012, 12, 783-793. [CrossRef]

29. Ahn, W.-S.; Yoo, J.; Huh, S.-W.; Kim, C.-K.; Lee, J.-M.; Namkoong, S.-E.; Bae, S.-M.; Lee, I.P. Protective effects of green tea extracts (polyphenon E and EGCG) on human cervical lesions. Eur. J. Cancer Prev. 2003, 12, 383-390. [CrossRef]

30. Shanafelt, T.D.; Call, T.G.; Zent, C.S.; Leis, J.F.; LaPlant, B.; Bowen, D.A.; Roos, M.; Laumann, K.; Ghosh, A.K.; Lesnick, C.; et al. Phase 2 trial of daily, oral polyphenon E in patients with asymptomatic, Rai stage 0 to II chronic lymphocytic leukemia. Cancer 2013, 119, 363-370. [CrossRef]

31. Wang, Y.; Jin, H.-Y.; Fang, M.-Z.; Wang, X.-F.; Chen, H.; Huang, S.-L.; Kong, D.-S.; Li, M.; Zhang, X.; Sun, Y.; et al. Epigallocatechin gallate inhibits dimethylhydrazine-induced colorectal cancer in rats. World J. Gastroenterol. 2020, 26, 2064-2081. [CrossRef]

32. Aggarwal, V.; Tuli, H.S.; Tania, M.; Srivastava, S.; Ritzer, E.E.; Pandey, A.; Aggarwal, D.; Barwal, T.S.; Jain, A.; Kaur, G.; et al. Molecular mechanisms of action of epigallocatechin gallate in cancer: Recent trends and advancement. Semin. Cancer Biol. 2020. [CrossRef]

33. Gan, R.-Y.; Li, H.-B.; Sui, Z.-Q.; Corke, H. Absorption, metabolism, anti-cancer effect and molecular targets of epigallocatechin gallate (EGCG): An updated review. Crit. Rev. Food Sci. Nutr. 2018, 58, 924-941. [CrossRef]

34. Yang, C.S.; Wang, X.; Lu, G.; Picinich, S.C. Cancer prevention by tea: Animal studies, molecular mechanisms and human relevance. Nat. Rev. Cancer 2009, 9, 429-439. [CrossRef]

35. Koessler, T.; Roth, A.; Cacheux, W. Early gastric cancer: Epidemiology, diagnostic and management. Rev. Med. Suisse 2014, 10, 1118-1122. [PubMed] 
36. Wang, Y.-Q.; Lu, J.-L.; Liang, Y.-R.; Li, Q.-S. Suppressive effects of EGCG on cervical cancer. Molecules 2018, 23, 2334. [CrossRef] [PubMed]

37. Shirakami, Y.; Shimizu, M. Possible mechanisms of green tea and its constituents against cancer. Molecules 2018, 23, 2284. [CrossRef] [PubMed]

38. Sharifi-Rad, M.; Pezzani, R.; Redaelli, M.; Zorzan, M.; Imran, M.; Ahmed Khalil, A.; Salehi, B.; Sharopov, F.; Cho, W.C.; Sharifi-Rad, J. Preclinical pharmacological activities of epigallocatechin-3-gallate in signaling pathways: An update on cancer. Molecules 2020, 25, 467. [CrossRef]

39. Musial, C.; Kuban-Jankowska, A.; Gorska-Ponikowska, M. Beneficial properties of green tea catechins. Int. J. Mol. Sci. 2020, 21, 1744. [CrossRef]

40. Lambert, J.D.; Elias, R.J. The antioxidant and pro-oxidant activities of green tea polyphenols: A role in cancer prevention. Arch. Biochem. Biophys. 2010, 501, 65-72. [CrossRef]

41. Khan, N.; Mukhtar, H. Tea polyphenols in promotion of human health. Nutrients 2018, 11, 39. [CrossRef]

42. Hayakawa, S.; Saito, K.; Miyoshi, N.; Ohishi, T.; Oishi, Y.; Miyoshi, M.; Nakamura, Y. Anti-cancer effects of green tea by either anti- or pro- oxidative mechanisms. Asian Pac. J. Cancer Prev. 2016, 17, 1649-1654. [CrossRef]

43. Ohishi, T.; Goto, S.; Monira, P.; Isemura, M.; Nakamura, Y. Anti-inflammatory action of green tea. Antiinflamm. Antiallergy Agents Med. Chem. 2016, 15, 74-90. [CrossRef]

44. Chen, P.C.; Wheeler, D.S.; Malhotra, V.; Odoms, K.; Denenberg, A.G.; Wong, H.R. A green tea-derived polyphenol, epigallocatechin-3-gallate, inhibits IkappaB kinase activation and IL-8 gene expression in respiratory epithelium. Inflammation 2002, 26, 233-241. [CrossRef]

45. Steinberg, G.R.; Michell, B.J.; van Denderen, B.J.W.; Watt, M.J.; Carey, A.L.; Fam, B.C.; Andrikopoulos, S.; Proietto, J.; Görgün, C.Z.; Carling, D.; et al. Tumor necrosis factor alpha-induced skeletal muscle insulin resistance involves suppression of AMP-kinase signaling. Cell Metab. 2006, 4, 465-474. [CrossRef] [PubMed]

46. Bulboaca, A.E.; Boarescu, P.-M.; Porfire, A.S.; Dogaru, G.; Barbalata, C.; Valeanu, M.; Munteanu, C.; Râjnoveanu, R.M.; Nicula, C.A.; Stanescu, I.C. The effect of nano-epigallocatechin-gallate on oxidative stress and matrix metalloproteinases in experimental diabetes mellitus. Antioxid. Basel 2020, 9, 172. [CrossRef] [PubMed]

47. Shankar, S.; Ganapathy, S.; Hingorani, S.R.; Srivastava, R.K. EGCG inhibits growth, invasion, angiogenesis and metastasis of pancreatic cancer. Front. Biosci. 2008, 13, 440-452. [CrossRef] [PubMed]

48. Tanabe, H.; Pervin, M.; Goto, S.; Isemura, M.; Nakamura, Y. Beneficial effects of plant polyphenols on obesity. Obes. Control Ther. 2017, 4, 1-16.

49. Collins, Q.F.; Liu, H.-Y.; Pi, J.; Liu, Z.; Quon, M.J.; Cao, W. Epigallocatechin-3-gallate (EGCG), a green tea polyphenol, suppresses hepatic gluconeogenesis through 5'-AMP-activated protein kinase. J. Biol. Chem. 2007, 282, 30143-30149. [CrossRef] [PubMed]

50. Kim, H.-S.; Quon, M.J.; Kim, J.-A. New insights into the mechanisms of polyphenols beyond antioxidant properties; lessons from the green tea polyphenol, epigallocatechin 3-gallate. Redox Biol. 2014, 2, 187-195. [CrossRef] [PubMed]

51. Salminen, A.; Hyttinen, J.M.T.; Kaarniranta, K. AMP-activated protein kinase inhibits NF- $\mathrm{kB}$ signaling and inflammation: Impact on healthspan and lifespan. J. Mol. Med. Berl. 2011, 89, 667-676. [CrossRef]

52. Xiang, H.-C.; Lin, L.-X.; Hu, X.-F.; Zhu, H.; Li, H.-P.; Zhang, R.-Y.; Hu, L.; Liu, W.-T.; Zhao, Y.-L.; Shu, Y.; et al. AMPK activation attenuates inflammatory pain through inhibiting NF- $\mathrm{KB}$ activation and IL-1 $\beta$ expression. $J$. Neuroinflamm. 2019, 16,34. [CrossRef]

53. Aggarwal, V.; Tuli, H.S.; Varol, A.; Thakral, F.; Yerer, M.B.; Sak, K.; Varol, M.; Jain, A.; Khan, M.A.; Sethi, G. Role of reactive oxygen species in cancer progression: Molecular mechanisms and recent advancements. Biomolecules 2019, 9, 735. [CrossRef]

54. Stark, T.; Livas, L.; Kyprianou, N. Inflammation in prostate cancer progression and therapeutic targeting. Transl. Androl. Urol. 2015, 4, 455-463.

55. Chen, C.-Y.; Kao, C.-L.; Liu, C.-M. The cancer prevention, anti-inflammatory and anti-oxidation of bioactive phytochemicals targeting the TLR4 Signaling Pathway. Int. J. Mol. Sci. 2018, 19, 2729. [CrossRef] [PubMed]

56. Cao, Y.; Liu, Q. Therapeutic targets of multiple angiogenic factors for the treatment of cancer and metastasis. Adv. Cancer Res. 2007, 97, 203-224. [PubMed] 
57. Bos, R.; Zhong, H.; Hanrahan, C.F.; Mommers, E.C.; Semenza, G.L.; Pinedo, H.M.; Abeloff, M.D.; Simons, J.W.; van Diest, P.J.; van der Wall, E. Levels of hypoxia-inducible factor-1 alpha during breast carcinogenesis. J. Natl. Cancer Inst. 2001, 93, 309-314. [CrossRef] [PubMed]

58. Koshikawa, N.; Iyozumi, A.; Gassmann, M.; Takenaga, K. Constitutive upregulation of hypoxia-inducible factor-1alpha mRNA occurring in highly metastatic lung carcinoma cells leads to vascular endothelial growth factor overexpression upon hypoxic exposure. Oncogene 2003, 22, 6717-6724. [CrossRef]

59. Fu, J.-D.; Yao, J.-J.; Wang, H.; Cui, W.-G.; Leng, J.; Ding, L.-Y.; Fan, K.-Y. Effects of EGCG on proliferation and apoptosis of gastric cancer SGC7901 cells via down-regulation of HIF-1 $\alpha$ and VEGF under a hypoxic state. Eur. Rev. Med. Pharmacol. Sci. 2019, 23, 155-161.

60. Gu, J.-W.; Makey, K.L.; Tucker, K.B.; Chinchar, E.; Mao, X.; Pei, I.; Thomas, E.Y.; Miele, L. EGCG, a major green tea catechin suppresses breast tumor angiogenesis and growth via inhibiting the activation of HIF- $1 \alpha$ and NFkB, and VEGF expression. Vasc. Cell 2013, 5, 9. [CrossRef]

61. Wu, D.; Liu, Z.; Li, J.; Zhang, Q.; Zhong, P.; Teng, T.; Chen, M.; Xie, Z.; Ji, A.; Li, Y. Epigallocatechin-3-gallate inhibits the growth and increases the apoptosis of human thyroid carcinoma cells through suppression of EGFR/RAS/RAF/MEK/ERK signaling pathway. Cancer Cell Int. 2019, 19, 43. [CrossRef]

62. Kondo, T.; Ohta, T.; Igura, K.; Hara, Y.; Kaji, K. Tea catechins inhibit angiogenesis in vitro, measured by human endothelial cell growth, migration and tube formation, through inhibition of VEGF receptor binding. Cancer Lett. 2002, 180, 139-144. [CrossRef]

63. Das, A.; Banik, N.L.; Ray, S.K. Flavonoids activated caspases for apoptosis in human glioblastoma T98G and U87MG cells but not in human normal astrocytes. Cancer 2010, 116, 164-176. [CrossRef]

64. Zan, L.; Chen, Q.; Zhang, L.; Li, X. Epigallocatechin gallate (EGCG) suppresses growth and tumorigenicity in breast cancer cells by downregulation of miR-25. Bioengineered 2019, 10, 374-382. [CrossRef]

65. Kwak, T.W.; Park, S.B.; Kim, H.-J.; Jeong, Y.-I.; Kang, D.H. Anticancer activities of epigallocatechin-3-gallate against cholangiocarcinoma cells. Onco. Targets. Ther. 2017, 10, 137-144. [CrossRef] [PubMed]

66. Jian, W.; Fang, S.; Chen, T.; Fang, J.; Mo, Y.; Li, D.; Xiong, S.; Liu, W.; Song, L.; Shen, J.; et al. A novel role of HuR in -Epigallocatechin-3-gallate (EGCG) induces tumour cells apoptosis. J. Cell. Mol. Med. 2019, 23, 3767-3771. [CrossRef] [PubMed]

67. Li, C.; Yang, W.; Zhang, J.; Zheng, X.; Yao, Y.; Tu, K.; Liu, Q. SREBP-1 has a prognostic role and contributes to invasion and metastasis in human hepatocellular carcinoma. Int. J. Mol. Sci. 2014, 15, 7124-7138. [CrossRef] [PubMed]

68. Yoon, J.Y.; Kwon, H.H.; Min, S.U.; Thiboutot, D.M.; Suh, D.H. Epigallocatechin-3-gallate improves acne in humans by modulating intracellular molecular targets and inhibiting P. acnes. J. Investig. Dermatol. 2013, 133, 429-440. [CrossRef]

69. Zhang, L.; Valizadeh, H.; Alipourfard, I.; Bidares, R.; Aghebati-Maleki, L.; Ahmadi, M. Epigenetic modifications and therapy in chronicobstructive pulmonary disease (COPD): An update review. COPD 2020, 17, 333-342. [CrossRef]

70. Sakamoto, N.; Honma, R.; Sekino, Y.; Goto, K.; Sentani, K.; Ishikawa, A.; Oue, N.; Yasui, W. Non-coding RNAs are promising targets for stem cell-based cancer therapy. Non-Coding RNA Res. 2017, 2, 83-87. [CrossRef]

71. Fang, M.Z.; Wang, Y.; Ai, N.; Hou, Z.; Sun, Y.; Lu, H.; Welsh, W.; Yang, C.S. Tea polyphenol (-)-epigallocatechin-3-gallate inhibits DNA methyltransferase and reactivates methylation-silenced genes in cancer cell lines. Cancer Res. 2003, 63, 7563-7570.

72. Pal, D.; Sur, S.; Roy, R.; Mandal, S.; Kumar Panda, C. Epigallocatechin gallate in combination with eugenol or amarogentin shows synergistic chemotherapeutic potential in cervical cancer cell line. J. Cell. Physiol. 2018, 234, 825-836. [CrossRef]

73. Khan, M.A.; Hussain, A.; Sundaram, M.K.; Alalami, U.; Gunasekera, D.; Ramesh, L.; Hamza, A.; Quraishi, U. (-)-Epigallocatechin-3-gallate reverses the expression of various tumor-suppressor genes by inhibiting DNA methyltransferases and histone deacetylases in human cervical cancer cells. Oncol. Rep. 2015, 33, 1976-1984. [CrossRef]

74. Zhu, Y.; Huang, Y.; Liu, M.; Yan, Q.; Zhao, W.; Yang, P.; Gao, Q.; Wei, J.; Zhao, W.; Ma, L. Epigallocatechin gallate inhibits cell growth and regulates miRNA expression in cervical carcinoma cell lines infected with different high-risk human papillomavirus subtypes. Exp. Ther. Med. 2018, 17, 1742-1748. [CrossRef] 
75. Wang, H.; Bian, S.; Yang, C.S. Green tea polyphenol EGCG suppresses lung cancer cell growth through upregulating miR-210 expression caused by stabilizing HIF-1 $\alpha$. Carcinogenesis 2011, 32, 1881-1889. [CrossRef] [PubMed]

76. Yamada, S.; Tsukamoto, S.; Huang, Y.; Makio, A.; Kumazoe, M.; Yamashita, S.; Tachibana, H. Epigallocatechin-3-O-gallate up-regulates microRNA-let-7b expression by activating 67-kDa laminin receptor signaling in melanoma cells. Sci. Rep. 2016, 6, 19225. [CrossRef] [PubMed]

77. Gordon, M.W.; Yan, F.; Zhong, X.; Mazumder, P.B.; Xu-Monette, Z.Y.; Zou, D.; Young, K.H.; Ramos, K.S.; Li, Y. Regulation of p53-targeting microRNAs by polycyclic aromatic hydrocarbons: Implications in the etiology of multiple myeloma. Mol. Carcinog. 2015, 54, 1060-1069. [CrossRef] [PubMed]

78. Hastak, K.; Gupta, S.; Ahmad, N.; Agarwal, M.K.; Agarwal, M.L.; Mukhtar, H. Role of p53 and NF-kappaB in epigallocatechin-3-gallate-induced apoptosis of LNCaP cells. Oncogene 2003, 22, 4851-4859. [CrossRef]

79. Hu, D.-L.; Wang, G.; Yu, J.; Zhang, L.-H.; Huang, Y.-F.; Wang, D.; Zhou, H.-H. Epigallocatechin-3-gallate modulates long non-coding RNA and mRNA expression profiles in lung cancer cells. Mol. Med. Rep. 2019, 19, 1509-1520. [CrossRef]

80. Sazuka, M.; Imazawa, H.; Shoji, Y.; Mita, T.; Hara, Y.; Isemura, M. Inhibition of collagenases from mouse lung carcinoma cells by green tea catechins and black tea theaflavins. Biosci. Biotechnol. Biochem. 1997, 61, 1504-1506. [CrossRef]

81. Bu, W.; Tang, Z.Y.; Sun, F.X.; Ye, S.L.; Liu, K.D.; Xue, Q.; Chen, J.; Gao, D.M. Effects of matrix metalloproteinase inhibitor BB-94 on liver cancer growth and metastasis in a patient-like orthotopic model LCI-D20. Hepatogastroenterology 1998, 45, 1056-1061.

82. Saeki, K.; Hayakawa, S.; Nakano, S.; Ito, S.; Oishi, Y.; Suzuki, Y.; Isemura, M. In vitro and in silico studies of the molecular interactions of epigallocatechin-3-O-gallate (EGCG) with proteins that explain the health benefits of green tea. Molecules 2018, 23, 1295. [CrossRef]

83. Nakano, S.; Megro, S.-I.; Hase, T.; Suzuki, T.; Isemura, M.; Nakamura, Y.; Ito, S. Computational molecular docking and X-ray crystallographic studies of catechins in new drug design strategies. Molecules 2018, 23, 2020. [CrossRef]

84. Umeda, D.; Yano, S.; Yamada, K.; Tachibana, H. Green tea polyphenol epigallocatechin-3-gallate signaling pathway through 67-kDa laminin receptor. J. Biol. Chem. 2008, 283, 3050-3058. [CrossRef]

85. Kumazoe, M.; Sugihara, K.; Tsukamoto, S.; Huang, Y.; Tsurudome, Y.; Suzuki, T.; Suemasu, Y.; Ueda, N.; Yamashita, S.; Kim, Y.; et al. 67-kDa laminin receptor increases cGMP to induce cancer-selective apoptosis. J. Clin. Investig. 2013, 123, 787-799. [CrossRef] [PubMed]

86. Negri, A.; Naponelli, V.; Rizzi, F.; Bettuzzi, S. Molecular targets of epigallocatechin-gallate (EGCG): A special focus on signal transduction and cancer. Nutrients 2018, 10, 1936. [CrossRef] [PubMed]

87. Wierzejska, R. Coffee consumption vs. cancer risk-a review of scientific data. Rocz. Panstw. Zakl. Hig. 2015, 66, 293-298. [PubMed]

88. Yu, M.C.; Mack, T.M.; Hanisch, R.; Cicioni, C.; Henderson, B.E. Cigarette smoking, obesity, diuretic use, and coffee consumption as risk factors for renal cell carcinoma. J. Natl. Cancer Inst. 1986, 77, 351-356. [PubMed]

89. Grubben, M.J.; Van Den Braak, C.C.; Broekhuizen, R.; De Jong, R.; Van Rijt, L.; De Ruijter, E.; Peters, W.H.; Katan, M.B.; Nagengast, F.M. The effect of unfiltered coffee on potential biomarkers for colonic cancer risk in healthy volunteers: A randomized trial. Aliment. Pharmacol. Ther. 2000, 14, 1181-1190. [CrossRef] [PubMed]

90. Steinkellner, H.; Hoelzl, C.; Uhl, M.; Cavin, C.; Haidinger, G.; Gsur, A.; Schmid, R.; Kundi, M.; Bichler, J.; Knasmüller, S. Coffee consumption induces GSTP in plasma and protects lymphocytes against (+/-)-anti-benzo[a]pyrene-7,8-dihydrodiol-9,10-epoxide induced DNA-damage: Results of controlled human intervention trials. Mutat. Res. 2005, 591, 264-275. [CrossRef]

91. Mišík, M.; Hoelzl, C.; Wagner, K.-H.; Cavin, C.; Moser, B.; Kundi, M.; Simic, T.; Elbling, L.; Kager, N.; Ferk, F.; et al. Impact of paper filtered coffee on oxidative DNA-damage: Results of a clinical trial. Mutat. Res. 2010, 692, 42-48. [CrossRef]

92. Loftfield, E.; Freedman, N.D. Coffee and digestive cancers-what do we know, and where do we go? Br. J. Cancer 2020, 122, 1273-1274. [CrossRef]

93. Zhao, L.-G.; Li, Z.-Y.; Feng, G.-S.; Ji, X.-W.; Tan, Y.-T.; Li, H.-L.; Gunter, M.J.; Xiang, Y.-B. Coffee drinking and cancer risk: An umbrella review of meta-analyses of observational studies. BMC Cancer 2020, 20, 101. [CrossRef] 
94. Yu, E.Y.W.; Dai, Y.; Wesselius, A.; van Osch, F.; Brinkman, M.; van den Brandt, P.; Grant, E.J.; White, E.; Weiderpass, E.; Gunter, M.; et al. Coffee consumption and risk of bladder cancer: A pooled analysis of 501,604 participants from 12 cohort studies in the BLadder Cancer Epidemiology and Nutritional Determinants (BLEND) international study. Eur. J. Epidemiol. 2020, 35, 523-535. [CrossRef]

95. Shaposhnikov, S.; Hatzold, T.; Yamani, N.E.; Stavro, P.M.; Lorenzo, Y.; Dusinska, M.; Reus, A.; Pasman, W.; Collins, A. Coffee and oxidative stress: A human intervention study. Eur. J. Nutr. 2018, 57, 533-544. [CrossRef] [PubMed]

96. Bamia, C.; Lagiou, P.; Jenab, M.; Trichopoulou, A.; Fedirko, V.; Aleksandrova, K.; Pischon, T.; Overvad, K.; Olsen, A.; Tjønneland, A.; et al. Coffee, tea and decaffeinated coffee in relation to hepatocellular carcinoma in a European population: Multicentre, prospective cohort study. Int. J. Cancer 2015, 136, 1899-1908. [CrossRef] [PubMed]

97. Hashibe, M.; Galeone, C.; Buys, S.S.; Gren, L.; Boffetta, P.; Zhang, Z.-F.; La Vecchia, C. Coffee, tea, caffeine intake, and the risk of cancer in the PLCO cohort. Br. J. Cancer 2015, 113, 809-816. [CrossRef] [PubMed]

98. Thomopoulos, T.P.; Ntouvelis, E.; Diamantaras, A.-A.; Tzanoudaki, M.; Baka, M.; Hatzipantelis, E.; Kourti, M.; Polychronopoulou, S.; Sidi, V.; Stiakaki, E.; et al. Maternal and childhood consumption of coffee, tea and cola beverages in association with childhood leukemia: A meta-analysis. Cancer Epidemiol. 2015, 39, 1047-1059. [CrossRef] [PubMed]

99. Milne, E.; Greenop, K.R.; Petridou, E.; Bailey, H.D.; Orsi, L.; Kang, A.Y.; Baka, M.; Bonaventure, A.; Kourti, M.; Metayer, C.; et al. Maternal consumption of coffee and tea during pregnancy and risk of childhood all: A pooled analysis from the childhood Leukemia International Consortium. Cancer Causes Control 2018, 29, 539-550. [CrossRef]

100. Hashemian, M.; Sinha, R.; Murphy, G.; Weinstein, S.J.; Liao, L.M.; Freedman, N.D.; Abnet, C.C.; Albanes, D.; Loftfield, E. Coffee and tea drinking and risk of cancer of the urinary tract in male smokers. Ann. Epidemiol. 2019, 34, 33-39. [CrossRef]

101. Hong, X.; Xu, Q.; Lan, K.; Huang, H.; Zhang, Y.; Chen, S.; Chi, Z.; Lin, J.; Zhou, Y.; Wu, W.; et al. The effect of daily fluid management and beverages consumption on the risk of bladder cancer: A meta-analysis of observational study. Nutr. Cancer 2018, 70, 1217-1227. [CrossRef]

102. Song, Y.; Wang, Z.; Jin, Y.; Guo, J. Association between tea and coffee consumption and brain cancer risk: An updated meta-analysis. World J. Surg. Oncol. 2019, 17, 51. [CrossRef]

103. Arthur, R.; Kirsh, V.A.; Rohan, T.E. Associations of coffee, tea and caffeine intake with risk of breast, endometrial and ovarian cancer among Canadian women. Cancer Epidemiol. 2018, 56, 75-82. [CrossRef]

104. Bradbury, K.E.; Murphy, N.; Key, T.J. Diet and colorectal cancer in UK Biobank: A prospective study. Int. J. Epidemiol. 2020, 49, 246-258. [CrossRef]

105. Quang, L.N.; Hien, N.Q.; Quang, N.T.; Chung, N.T. Active lifestyle patterns reduce the risk of colorectal cancer in the north of Vietnam: A hospital-based case-control study. Cancer Control 2019, 26, 1073274819864666. [CrossRef] [PubMed]

106. Cote, D.J.; Bever, A.M.; Wilson, K.M.; Smith, T.R.; Smith-Warner, S.A.; Stampfer, M.J. A prospective study of tea and coffee intake and risk of glioma. Int. J. Cancer 2020, 146, 2442-2449. [CrossRef] [PubMed]

107. Malmir, H.; Shayanfar, M.; Mohammad-Shirazi, M.; Tabibi, H.; Sharifi, G.; Esmaillzadeh, A. Tea and coffee consumption in relation to glioma: A case-control study. Eur. J. Nutr. 2019, 58, 103-111. [CrossRef]

108. Ugai, T.; Matsuo, K.; Sawada, N.; Iwasaki, M.; Yamaji, T.; Shimazu, T.; Goto, A.; Inoue, M.; Kanda, Y.; Tsugane, S.; et al. Coffee and green tea consumption and subsequent risk of acute myeloid leukemia and myelodysplastic syndromes in Japan. Int. J. Cancer 2018, 142, 1130-1138. [CrossRef]

109. Karalexi, M.A.; Dessypris, N.; Clavel, J.; Metayer, C.; Erdmann, F.; Orsi, L.; Kang, A.Y.; Schüz, J.; Bonaventure, A.; Greenop, K.R.; et al. Coffee and tea consumption during pregnancy and risk of childhood acute myeloid leukemia: A Childhood Leukemia International Consortium (CLIC) study. Cancer Epidemiol. 2019, 62, 101581. [CrossRef]

110. Tamura, T.; Wada, K.; Konishi, K.; Goto, Y.; Mizuta, F.; Koda, S.; Hori, A.; Tanabashi, S.; Matsushita, S.; Tokimitsu, N.; et al. Coffee, green tea, and caffeine intake and liver cancer risk: A prospective cohort study. Nutr. Cancer 2018, 70, 1210-1216. [CrossRef] [PubMed]

111. Seow, W.J.; Koh, W.-P.; Jin, A.; Wang, R.; Yuan, J.-M. Associations between tea and coffee beverage consumption and the risk of lung cancer in the Singaporean Chinese population. Eur. J. Nutr. 2019, 59, 3083-3091. [CrossRef] 
112. Mirtavoos-Mahyari, H.; Salehipour, P.; Parohan, M.; Sadeghi, A. Effects of coffee, black tea and green tea consumption on the risk of non-Hodgkin's lymphoma: A systematic review and dose-response meta-analysis of observational studies. Nutr. Cancer 2019, 71, 887-897. [CrossRef]

113. Fortes, C. Are anti-inflammatory foods associated with a protective effect for cutaneous melanoma? Eur. J. Cancer Prev. 2020. [CrossRef]

114. Sen, A.; Papadimitriou, N.; Lagiou, P.; Perez-Cornago, A.; Travis, R.C.; Key, T.J.; Murphy, N.; Gunter, M.; Freisling, H.; Tzoulaki, I.; et al. Coffee and tea consumption and risk of prostate cancer in the European Prospective Investigation into Cancer and Nutrition. Int. J. Cancer 2019, 144, 240-250. [CrossRef]

115. Oh, C.C.; Jin, A.; Yuan, J.-M.; Koh, W.-P. Coffee, tea, caffeine, and risk of nonmelanoma skin cancer in a Chinese population: The Singapore Chinese health study. J. Am. Acad. Dermatol. 2019, 81, 395-402. [CrossRef] [PubMed]

116. Zamora-Ros, R.; Alghamdi, M.A.; Cayssials, V.; Franceschi, S.; Almquist, M.; Hennings, J.; Sandström, M.; Tsilidis, K.K.; Weiderpass, E.; Boutron-Ruault, M.-C.; et al. Coffee and tea drinking in relation to the risk of differentiated thyroid carcinoma: Results from the European Prospective Investigation into Cancer and Nutrition (EPIC) study. Eur. J. Nutr. 2019, 58, 3303-3312. [CrossRef] [PubMed]

117. Shimizu, M.; Yoshimi, N.; Yamada, Y.; Matsunaga, K.; Kawabata, K.; Hara, A.; Moriwaki, H.; Mori, H. Suppressive effects of chlorogenic acid on N-methyl-N-nitrosourea-induced glandular stomach carcinogenesis in male F344 rats. J. Toxicol. Sci. 1999, 24, 433-439. [CrossRef] [PubMed]

118. Salomone, F.; Galvano, F.; Li Volti, G. Molecular bases underlying the hepatoprotective effects of coffee. Nutrients 2017, 9, 85. [CrossRef] [PubMed]

119. Miura, Y.; Furuse, T.; Yagasaki, K. Inhibitory effect of serum from rats administered with coffee on the proliferation and invasion of rat ascites hepatoma cells. Cytotechnology 1997, 25, 221-225. [CrossRef] [PubMed]

120. Hou, N.; Liu, N.; Han, J.; Yan, Y.; Li, J. Chlorogenic acid induces reactive oxygen species generation and inhibits the viability of human colon cancer cells. Anticancer Drugs 2017, 28, 59-65. [CrossRef] [PubMed]

121. Feng, R.; Lu, Y.; Bowman, L.L.; Qian, Y.; Castranova, V.; Ding, M. Inhibition of activator protein-1, NF-kappaB, and MAPKs and induction of phase 2 detoxifying enzyme activity by chlorogenic acid. J. Biol. Chem. 2005, 280, 27888-27895. [CrossRef]

122. Liang, N.; Kitts, D.D. Role of chlorogenic acids in controlling oxidative and inflammatory stress conditions. Nutrients 2015, 8, 16. [CrossRef]

123. Cha, J.W.; Piao, M.J.; Kim, K.C.; Yao, C.W.; Zheng, J.; Kim, S.M.; Hyun, C.L.; Ahn, Y.S.; Hyun, J.W. The polyphenol chlorogenic acid attenuates UVB-mediated oxidative stress in human HaCaT keratinocytes. Biomol. Ther. 2014, 22, 136-142. [CrossRef]

124. Rakshit, S.; Mandal, L.; Pal, B.C.; Bagchi, J.; Biswas, N.; Chaudhuri, J.; Chowdhury, A.A.; Manna, A.; Chaudhuri, U.; Konar, A.; et al. Involvement of ROS in chlorogenic acid-induced apoptosis of Bcr-Abl+ CML cells. Biochem. Pharmacol. 2010, 80, 1662-1675. [CrossRef]

125. Hwang, S.J.; Kim, Y.-W.; Park, Y.; Lee, H.-J.; Kim, K.-W. Anti-inflammatory effects of chlorogenic acid in lipopolysaccharide-stimulated RAW 264.7 cells. Inflamm. Res. 2014, 63, 81-90. [CrossRef] [PubMed]

126. Kim, J.; Lee, Y.M.; Jung, W.; Park, S.-B.; Kim, C.-S.; Kim, J.S. Aster koraiensis extract and chlorogenic acid inhibit retinal angiogenesis in a mouse model of oxygen-induced retinopathy. Evid. Based Complement. Alternat. Med. 2018, 2018, 6402650. [CrossRef] [PubMed]

127. Lukitasari, M.; Nugroho, D.A.; Widodo, N. Chlorogenic acid: The conceivable chemosensitizer leading to cancer growth suppression. J. Evid. Based Integr. Med. 2018, 23, 2515690X18789628. [CrossRef] [PubMed]

128. Mitrea, D.R.; Malkey, R.; Florian, T.L.; Filip, A.; Clichici, S.; Bidian, C.; Moldovan, R.; Hoteiuc, O.A.; Toader, A.M.; Baldea, I. Daily oral administration of chlorogenic acid prevents the experimental carrageenan-induced oxidative stress. J. Physiol. Pharmacol. 2020, 71. [CrossRef]

129. Wang, X.; Liu, J.; Xie, Z.; Rao, J.; Xu, G.; Huang, K.; Li, W.; Yin, Z. Chlorogenic acid inhibits proliferation and induces apoptosis in A498 human kidney cancer cells via inactivating PI3K/Akt/mTOR signalling pathway. J. Pharm. Pharmacol. 2019, 71, 1100-1109. [CrossRef] [PubMed]

130. Park, S.Y.; Jin, M.L.; Yi, E.H.; Kim, Y.; Park, G. Neochlorogenic acid inhibits against LPS-activated inflammatory responses through up-regulation of Nrf2/HO-1 and involving AMPK pathway. Environ. Toxicol. Pharmacol. 2018, 62, 1-10. [CrossRef] [PubMed] 
131. Liu, Y.; Feng, Y.; Li, Y.; Hu, Y.; Zhang, Q.; Huang, Y.; Shi, K.; Ran, C.; Hou, J.; Zhou, G.; et al. Chlorogenic acid decreases malignant characteristics of hepatocellular carcinoma cells by inhibiting DNMT1 expression. Front. Pharmacol. 2020, 11, 867. [CrossRef] [PubMed]

132. Lee, W.J.; Zhu, B.T. Inhibition of DNA methylation by caffeic acid and chlorogenic acid, two common catechol-containing coffee polyphenols. Carcinogenesis 2006, 27, 269-277. [CrossRef]

133. Mira, A.; Shimizu, K. In vitro cytotoxic activities and molecular mechanisms of angelica shikokiana extract and its isolated compounds. Pharmacogn. Mag. 2015, 11, S564-S569.

134. Liu, H.; Guo, X.; Liu, J.; Xue, F.; Bai, G.; Liang, Y. Chlorogenic-induced inhibition of non-small cancer cells occurs through regulation of histone deacetylase 6. Cell. Mol. Biol. 2018, 64, 134-139.

135. Bora-Tatar, G.; Dayangaç-Erden, D.; Demir, A.S.; Dalkara, S.; Yelekçi, K.; Erdem-Yurter, H. Molecular modifications on carboxylic acid derivatives as potent histone deacetylase inhibitors: Activity and docking studies. Bioorg. Med. Chem. 2009, 17, 5219-5228. [CrossRef] [PubMed]

136. Yang, F.; Luo, L.; Zhu, Z.-D.; Zhou, X.; Wang, Y.; Xue, J.; Zhang, J.; Cai, X.; Chen, Z.-L.; Ma, Q.; et al. Chlorogenic acid inhibits liver fibrosis by blocking the miR-21-regulated TGF- $\beta 1 / \mathrm{Smad} 7$ signaling pathway in vitro and in vivo. Front. Pharmacol. 2017, 8, 929. [CrossRef] [PubMed]

137. Wang, Y.; Yang, F.; Xue, J.; Zhou, X.; Luo, L.; Ma, Q.; Chen, Y.-F.; Zhang, J.; Zhang, S.-L.; Zhao, L. Antischistosomiasis liver fibrosis effects of chlorogenic acid through IL-13/miR-21/Smad7 signaling interactions in vivo and in vitro. Antimicrob. Agents Chemother. 2017, 61, e01347:1-e01347:16. [CrossRef] [PubMed]

138. Roehlen, N.; Crouchet, E.; Baumert, T.F. Liver fibrosis: Mechanistic concepts and therapeutic perspectives. Cells 2020, 9, 875. [CrossRef] [PubMed]

139. Huang, S.; Wang, L.-L.; Xue, N.-N.; Li, C.; Guo, H.-H.; Ren, T.-K.; Zhan, Y.; Li, W.-B.; Zhang, J.; Chen, X.-G.; et al. Chlorogenic acid effectively treats cancers through induction of cancer cell differentiation. Theranostics 2019, 9, 6745-6763. [CrossRef]

140. Dong, K.F.; Huo, M.Q.; Sun, H.Y.; Li, T.K.; Li, D. Mechanism of Astragalus membranaceus in the treatment of laryngeal cancer based on gene co-expression network and molecular docking. Sci. Rep. 2020, 10, 11184. [CrossRef]

141. Orlando, G.; Recinella, L.; Chiavaroli, A.; Brunetti, L.; Leone, S.; Carradori, S.; Di Simone, S.; Ciferri, M.C.; Zengin, G.; Ak, G.; et al. Water extract from inflorescences of industrial hemp futura 75 variety as a source of anti-inflammatory, anti-proliferative and antimycotic agents: Results from in silico, in vitro and ex vivo studies. Antioxidants 2020, 9, 437. [CrossRef]

142. Elfiky, A.A. Natural products may interfere with SARS-CoV-2 attachment to the host cell. J. Biomol. Struct. Dyn. 2020, 1-10. [CrossRef]

143. Ahmad, B.; Rizwan, M.; Rauf, A.; Raza, M.; Bashir, S.; Molnar, J.; Csonka, A.; Szabo, D.; Mubarak, M.S.; Noor, M.; et al. Isolation of chlorogenic acid from soil borne fungi Screlotium rolfsii, their reversal of multidrug resistance and anti-proliferative in mouse lymphoma Cells. Med. Chem. 2017, 13, 721-726. [CrossRef]

144. Deka, S.J.; Gorai, S.; Manna, D.; Trivedi, V. Evidence of PKC binding and translocation to explain the anticancer mechanism of chlorogenic acid in breast cancer cells. Curr. Mol. Med. 2017, 17, 79-89. [CrossRef]

145. Taha, K.F.; Khalil, M.; Abubakr, M.S.; Shawky, E. Identifying cancer-related molecular targets of Nandina domestica Thunb. by network pharmacology-based analysis in combination with chemical profiling and molecular docking studies. J. Ethnopharmacol. 2020, 249, 112413. [CrossRef] [PubMed]

146. Hirose, M.; Masuda, A.; Imaida, K.; Kagawa, M.; Tsuda, H.; Ito, N. Induction of forestomach lesions in rats by oral administrations of naturally occurring antioxidants for 4 weeks. Jpn. J. Cancer Res. 1987, 78, 317-321. [PubMed]

147. Hirose, M.; Fukushima, S.; Shirai, T.; Hasegawa, R.; Kato, T.; Tanaka, H.; Asakawa, E.; Ito, N. Stomach carcinogenicity of caffeic acid, sesamol and catechol in rats and mice. Jpn. J. Cancer Res. 1990, 81, 207-212. [CrossRef] [PubMed]

(C) 2020 by the authors. Licensee MDPI, Basel, Switzerland. This article is an open access article distributed under the terms and conditions of the Creative Commons Attribution (CC BY) license (http://creativecommons.org/licenses/by/4.0/). 